ORIGINAL RESEARCH ARTICLE

\title{
The Role and Effectiveness of Corporate Social Responsibility Assurance in a Mandatory Setting: Professional Accountants' Perceptions
}

\author{
Isabelle Martinez ${ }^{*}$, Claire Gillet-Monjarret², and Géraldine Rivière-Giordano² \\ ITMS-R (UMR 5303 CNRS), University of Toulouse I Capitole, Toulouse, France \\ 2MRM University of Montpellier, Montpellier, France
}

\begin{abstract}
Firms using corporate social responsibility assurance (or CSRA) recruit an external and independent third party to undertake assurance of the corporate social responsibility (CSR) information that they disclose. From a theoretical perspective, CSRA may play a role within two distinct mechanisms: the signaling mechanism, whereby CSRA signals both the quality of the disclosed information and firms' CSR performance, and the legitimizing mechanism, whereby CSRA is strategically used as a 'sophisticated' compliance exercise. Thus, while the signaling theory predicts that CSRA should provide the expected benefits for its intended users, studies based on the legitimacy theory question the effectiveness of CSRA. In an attempt to disentangle which mechanism is dominant, this study investigates how professional accountants, as assurance providers, perceive CSRA and its effectiveness. We use an online questionnaire survey involving a between-subjects experimental design with 104 French professional accountants as participants. The quantitative and qualitative results suggest, in line with legitimacy theory, that CSRA is used more as a compliance exercise than as an effective signal. We advance the idea that in the French setting, in which CSRA is mandatory, it is used by firms to create the illusion of transparency by complying with disclosure requirements. However, we offer an alternative interpretation by arguing that some professional accountants may in fact seek to resist the implementation of mandatory CSRA using a strategy of justification.
\end{abstract}

Keywords: Corporate social responsibility; Sustainable assurance; Experimental questionnaire; Professional accountants

Handling Editor:Thomas Roulet; Received: I I March 2020; Accepted: 24 May 2020; Published: 19 March 202 I

C ompanies have to disclose increasingly more information regarding their corporate social responsibility (CSR) performance. However, CSR reporting is frequently viewed as strategic in nature and insufficiently credible.' To address this concern, firms use external assurance for their reports (Braam \& Peeters, 2018; Clarkson et al., 2019; Larrinaga, Rossi, LuqueVilchez, \& Núñez-Nickel, 20|8). For example, a KPMG (2017) survey reports that more than two-thirds (67\%) of G250 companies voluntarily assured their CSR reports in 2017 (the proportion of assuring firms was $40 \%$ in 2008).

Corporate social responsibility assurance (or CSRA) is defined as an engagement in which a firm recruits an external and independent third party to undertake assurance of their

\footnotetext{
Note that Le Breton and Aggeri (2018) explain the conditions under which carbon accounting practices could help enact CSR in companies.
}

CSR reports (Farooq \& DeVilliers, 20 17). Assurance providers frequently fall into two categories: professional accountants (such as Big 4 and non-Big 4 firms) or CSR experts (such as engineering firms, certification bodies, and Non-Governmental Organizations [NGOs]). The role of the assurance provider is to produce an assurance statement offering conclusions on the information contained in CSR reports. Firms also choose between two levels of assurance: high (reasonable) and limited (moderate). The level of assurance is determined before the assurance preparation itself and is contractually agreed upon by the company and the assurance provider. A reasonable assurance statement requires a more stringent and thorough evaluation of the CSR information contained in the report (Boiral, Heras-Saizarbitoria, Brotherton, \& Bernard, 2019).

From a theoretical perspective, firms, by using CSRA, trigger two mechanisms that could have different effects: the signaling

*Corresponding author: Isabelle Martinez, Email: isabelle.martinez@tsm-education.fr

JEL classification: M4 I 
mechanism, whereby firms use CSRA to signal the quality of disclosed information as well as their CSR performance, and the legitimizing mechanism, whereby firms strategically use CSRA to convince stakeholders that they operate in accordance with their expectations. The first stream of literature, based on signaling theory, supports the idea that intended users benefit from assurance: the assured CSR information should be more relevant (i.e., useful for decision-making) and more trustworthy ${ }^{2}$ than the CSR information provided without assurance (e.g., Ballou, Chen, Grenier, \& Heitger, 2018; Carey, Simnett, \& Tanewski, 2000; Cho, Michelon, \& Patten, 2014; Hodge, Subramaniam, \& Stewart, 2009; Pflugrath, Roebuck, \& Simnett, 201 I). Indeed, as indicated by the term 'assurance itself,' CSRA allows firms to assure the readers of their reports that the contents disclosed are true and have been verified by a third party. This is consistent with the Global Reporting Initiative (GRI, 20I3), in which CSRA serves to build trust and confidence in the areas of governance, management, and stakeholder relations. A second stream of literature, based on legitimacy theory, argues that, due to managerial capture, which refers to management's control of CSR information, CSRA is just a 'sophisticated' compliance exercise or a symbol of legitimacy (e.g., Ball, Owen, \& Gray, 2000; Cohen \& Simnett, 2015; Gürtürk \& Hahn, 20 16; Hummel, Schlick, \& Fifka, 2019; Power, 1991, 1997; O'Dwyer, 2003; O'Dwyer \& Owen, 2005, 2007; Owen, Swift, Humphrey, \& Bowerman, 2000; Romero, Fernandez-Feijoo, \& Ruiz, 2014; Smith, Haniffa, \& Fairbrass, $20 \mathrm{II}$ ). Authors criticize the practice of CSRA and raise doubts around its effectiveness, defined in terms of value added or benefits for intended users. Several factors (e.g., the lack of standardization) limit the contribution of assurance providers (Goicoechea, Gomez-Bezares, \& Ugarte, 2019) and could counter the quality of CSRA. Thus, CSRA currently suffers from an expectation gap ${ }^{3}$ (Green \& Li, 20 I2; Hodge et al., 2009).

In brief, the academic literature on CSRA remains divided on the role of CSRA and its consequent effectiveness. Nevertheless, Pennings (2017) notes that research on the effectiveness of CSRA remains rare, specifically for European markets. It is also surprising that the views of assurance providers themselves have been mainly overlooked in the CSRA literature (Boiral, Heras-Saizarbitoria, Brotherton, \& Bernard, 2019; Boiral, Heras-Saizarbitoria, \& Brotherton, 2019). This study aims to fill this gap and to disentangle which of the two theoretical perspectives on CSRA is more empirically

\footnotetext{
2. Information quality is defined as having two characteristics: information credibility and relevance (Habek \&Wolniak, 20 I5). To be considered credible, CSR information must be understandable to readers and trustworthy (Lock \& Seele, 2017).

3. An expectation gap exists when different beliefs regarding the level of effectiveness of assurance are held by firms, assurers, and the users of the information.
}

relevant by investigating how professional accountants, as assurance providers, perceive CSRA and its effectiveness.

We focus on professional accountants because a large majority of firms call on them for assurance of CSR information Larrinaga et al. (2018). For example, KPMG (2015) reported that in $2015,65 \%$ of the assurance statements for the CSR reports of G250 companies were provided by accounting firms. This proportion increases to $88.67 \%$ among the assurance statements issued for a sample of firms located in 24 European countries (Pennings, 2017). One major explanation is that the provision of assurance services by professional accountants is likely to improve the quality of CSRA (Hummel et al., 2019; Zorio, Garcia-Benau, \& Sierra, 2013). Thus, in view of the major role that professional accountants seem to play in CSRA, we investigate whether they acknowledge the expected benefits of assurance of CSR information. First, through a quantitative approach, we investigate whether the presence of assurance as well as the type of assurance provider and the level of assurance impact the perceived relevance of CSR information and the confidence in this information in the eyes of professional accountants. Second, by using qualitative analysis, we gain a more in-depth understanding of what professional accountants, as assurance providers, think about the effectiveness of CSRA.

We also focus on a specific context in which CSRA is required. While CSRA is still voluntary in most countries, France made CSRA mandatory with the adoption of the Grenelle 2 law ( $n^{\circ}$ 2010-788) in 2010. In adopting this law, French institutions seek to enhance the effectiveness of CSRA (Gillet-Monjarret, 2018). Thus, it may be interesting to see what the consequences of making CSRA mandatory are from the point of view of assurance providers themselves.

We use an online questionnaire survey involving a between-subjects experimental design. A total of 104 French professional accountants participated in this study. The questionnaire contains closed and open questions and allows for the collection of both quantitative and qualitative data. The quantitative results show that CSRA does not impact the perceived relevance of CSR information and participants' confidence in the information disclosed. In addition, neither the type of assurance provider nor the level of assurance enhances professional accountants' perceptions. Regarding the qualitative results, they show that professional accountants question their own mission in providing CSRA. Based on our data coding, we identify four general topics attracting professional accountants' attention: the characteristics of CSR data, the content of CSRA statements, the lack of standardization, and their own illiteracy regarding CSR issues.

Taken together, our results contradict the existence of a signaling effect of CSRA and align with criticisms of CSRA based on legitimacy theory. Such criticisms suggest that CSRA is more of a compliance exercise than an effective signal of the quality of 
CSR information. We advance the idea that CSRA, in the French mandatory setting, is used by firms to create the illusion of transparency by complying with disclosure requirements. Additionally, these results indicate that making CSRA mandatory, as France has done, does not enhance the effectiveness of assurance.

However, we offer an alternative interpretation of our findings. By making CSRA mandatory for the largest companies, France inaugurated a new market for CSRA, in which all accounting firms of any type and size are recognized as competent to carry out CSR assurance engagement. As noted by Taupin (20/2), in the event of change in an institutional field, tensions emerge with the presence of different logics that can be in competition with each other, with, in this case, some accountant firms (non-Big 4) seeking to resist change and maintain the status quo and others (Big 4) opposing that aim. Thus, we suggest that the reasons given by professional accountants participating in our study to justify their skepticism of CSRA could serve as a strategy of justification for resisting changes and/or avoiding new responsibilities.

Our study makes several contributions. First, it contributes to the current literature on CSRA by disentangling two theoretical approaches to this question based on the signaling and legitimacy theories. By showing that professional accountants do not acknowledge the benefits of CSRA and have concerns with their own mission in CSRA, we hope to advance the understanding of the role of CSRA as well as of its consequent effectiveness. Second, while most experimental studies on the benefits of CSRA have used students as participants, our research deploys an experimental questionnaire with professional accountants. This methodology also allows us to collect quantitative and qualitative data to examine in-depth the perceptions of professionals on the expected benefits of CSRA and its effectiveness. Finally, the results may shed interesting light on standard setters and regulatory bodies. As noted by Pennings (2017), there has been a widespread call for increased regulation, but our results suggest that making CSRA mandatory does not necessarily enhance its effectiveness.

The remainder of the article proceeds as follows. Firstly, we present the institutional and theoretical framework. Secondly, we review the prior literature, highlighting the expected benefits of CSRA and the factors that challenge the effectiveness of CSRA and thus leads to an expectation gap. Thirdly, we describe the research design before presenting the quantitative and qualitative results, respectively. Finally, we offer a discussion and conclusion.

\section{Institutional and theoretical framework Institutional setting}

As noted by Larrinaga et al. (2018), the practice of CSRA may now be deemed a norm in many countries, specifically in European countries. In Europe, reporting on environmental, social, and governance matters has recently taken a major step forward with the publication of the European Directive 20 I 4/95/ EU. Approximately 6,000 firms are now required to report non-financial information under the Directive from 2017 onwards. ${ }^{4}$ According to the Directive, a country has the option to have the CSR information "verified" by an independent assurance provider. If implemented, this verification results in an assurance engagement. The International Audit Assurance Standards Board (201 I, p. 19) defines an assurance engagement as "an engagement in which a practitioner aims to obtain sufficient appropriate evidence in order to express a conclusion designed to enhance the degree of confidence of the intended users other than the responsible party about the outcome of the measurement or evaluation of an underlying subject matter against criteria." The overall objective of an assurance engagement is to enhance the credibility of information and the users' confidence (Cheng, Green, \& Chi Wa Ko, 2015; Hassan, Elamer, Sobhan, \& Fletcher, 2019; Hodge et al., 2009).

In France, as noted in Directive 2014/95/EU, CSRA has been mandatory since the adoption of the Grenelle 2 law in 2010 . The implementing decree, issued in 2012 ( $n^{\circ} 2012-557$ ), stipulates that this law applies to the largest French companies and that CSRA must be provided by an independent third party approved by the French Accreditation Committee (COFRAC). ${ }^{5}$ Some companies anticipated this regulation and complied with it in previous years.

The 2012 decree also states that the assurance statement must include (I) a clear indication of the procedures applied; (2) conclusions on the presence (or not) in the report of the CSR information required by the Grenelle 2 law ${ }^{6}$; and (3) an opinion, including reasons, on the accuracy of the information or explanations for why certain topics were omitted. Note that in France, in contrast with Anglo-Saxon countries, where CSR information is disclosed in stand-alone CSR reports, CSR information is usually contained in annual reports.

In addition, a ministerial order of May 13, 2013 (JORF $\left.n^{\circ} 0136\right)$ regulates the practical arrangements for CSRA, specifying the methods to be used by the assurance provider. The French National Institute of Auditors (CNCC) has promulgated a professional practice standard for $\mathrm{CSRA}^{7}$ that specifies how the assurance provider's mission must be conducted and

\footnotetext{
4. https://www.ifac.org/knowledge-gateway/audit-assurance/discussion/ external-assurance-non-financial-information-providing

5. Mandatory CSRA became effective for the fiscal years beginning after December 3 I, 20 I I, for listed companies and after December 31, 20 I , for non-listed companies with annual sales and a balance sheet total in excess of $€ 100$ million and an average permanent workforce of more than 500 .

6. France's 2012 decree advocates the 'comply or explain' principle, whereby companies can either comply with disclosure requirements or explain why they do not comply.

7. NEP 9090: Assurance service relating to social and environmental information included within the framework of reviews that is linked directly to the statutory audit mission.
} 
that covers other CSR reporting-related services that auditors can initiate, such as partial statements, consultations, or agreed ad hoc procedures. The standard also distinguishes two types of assurance engagement: a reasonable assurance engagement (a high but not absolute level of assurance) and a limited assurance engagement (a moderate or low level of assurance). These statements are in line with the requirements of the International Standard on Assurance Engagements ISAE 3000.

In practice, assurance providers are either professional accountants (such as Big 4 and non-Big 4 firms) or CSR experts (such as engineering firms, certification bodies, and NGOs). In France, the Grenelle 2 law and professional standard (NEP 9090) clearly designate professional accountants as being competent actors to conduct the mission of CSR assurance. The accountants are expected to play a critical role in the protection of stakeholders' interests by ensuring the publication of truthful, complete, and timely information to them. They are presumed to be able to assess the quality of accounting, financial and now CSR information with independence, objectivity, and integrity. Thus, the economic role of external auditors is to reduce the risks for information users. The auditor's opinion is essentially intended to make the information disclosed by firms more credible, i.e., to increase the usefulness of the information for users in a situation of asymmetry. In other words, by adopting the Grenelle 2 law, French institutions can be expected to enhance the effectiveness of CSRA (GilletMonjarret, 2018). Islam and Dellaportas (20II) note the importance of institutional pressure for developing CSR accounting and reporting practices: even if accountants have positive attitudes, progress is limited in the absence of institutional forces (such as the government and a major accounting body), making noticeable efforts to develop such practices.

\section{Theoretical perspectives on the role of CSRA}

Previous research has often built upon the signaling and legitimacy theories to understand the role of CSRA. Why does a company voluntarily incur costs to have its CSR information assured by a third, external and independent party? As noted above, while CSRA is voluntary in most countries, France has made CSRA mandatory. However, the question remains quite similar, as companies can choose from a large range of providers charging varying rates for CSRA provision. Within this context, some firms voluntarily decide to spend more money and incur additional costs to have their CSR information assured by professional accountants rather than by CSR experts, or vice versa. In addition to the provider, companies have to decide on the level of assurance statement, the reasonable level being accompanied by a higher fee (GRI, 20I3).

As noted by Hummel et al. (2019), the key mechanism in the process of CSRA is signaling. As indicated by the term 'assurance itself', firms try to assure the readers of their reports that the contents disclosed are true and have been verified by a third party. This assurance signals the quality of CSR reporting. Signaling theory posits that there is an information asymmetry between insiders and outsiders, the former being the party with the information advantage over the latter. Due to this information advantage, companies have extensive latitude in choosing what to report. More specifically, in the case of CSR reporting, Touboul and Kozan (2020) noted that firms with high CSR performance use extensive disclosure to reveal their performance, whereas firms with low performance tend to limit their disclosure and to provide low-quality (or noisy) information. Faced with this difficulty, the reader alone is unable to judge the quality of information and, in particular, if it is true. Thus, the role of CSRA is crucial: it signals to stakeholders that they can trust the content disclosed in CSR reports because it has been guaranteed by an external and independent third party (Cheng et al., 20 I5). In that sense, CSRA itself constitutes a disclosure credibility signal (e.g., Brown-Liburd \& Zamora, 20I5). It results in decreasing information asymmetry between managers and stakeholders and, consequently, decreasing principal-agent conflicts.

Note that two conditions are necessary for a signal to produce the result the signaler desires. First, the signal needs to be observable by the public. Second, to avoid ineffective signaling, the signal needs to be costly. Thus, companies with superior (or good) CSR performance are more likely to spend additional resources on CSRA than companies with inferior (or bad) CSR performance to differentiate themselves from 'greenwashed' companies (Braam \& Peeters, 2018; Cheng et al., 20l5; Zhou, Simnett, \& Green, 2016). Thus, in addition to signal information quality, CSRA also signals that management considers CSR performance as an important aspect of corporate performance (Braam \& Peeters, 20 I 8; Cheng et al., 20 15; Zhou et al., 20 I6).

In contrast with the signaling perspective, legitimacy theory suggests that companies with poor performance could strategically use CSRA to create a positive corporate image and influence users' perceptions. Thus, some authors derive a critical picture of CSRA, in which assurance is viewed as a 'sophisticated' compliance exercise and a symbol of legitimacy (e.g., Cho \& Patten, 2007; Michelon, Pilonato, \& Ricceri, 2015; Power, 1991, 1997; O'Dwyer, 2003; O'Dwyer \& Owen, 2005). This stream of literature emphasizes the legitimating effect of assurance, highlighting the existence of managerial capture of assurance providers (e.g., Hummel et al., 2019; Michelon et al., 2015). Managerial capture is defined as the process by which management takes control of CSRA by only providing information that presents the company in a favorable light and by reporting the information in a way that is likely to maximize shareholder value (O'Dwyer, 2003; O'Dwyer \& Owen, 2005). According to Cho et al. (20I5), contradictory societal and institutional pressures lead companies to engage in hypocrisy and develop façades such that, even when 
CSR information is assured, a gap persists between the reporting and actual managerial practices. In other words, firms systematically fail to disclose bad news, and CSR reporting is mainly used for 'greenwashing.' To this end, firms seek to influence the opinions of assurance providers (Hummel et al., 2019; Michelon et al., 2015), and for Hummel et al. (2019), such capture has severe ethical implications. It prevents auditors from objectively and independently addressing the quality of information reported by firms in such a way that the veracity of conclusions given in the CSRA statements raises concerns. Therefore, CSRA is more a sophisticated compliance exercise or a symbol of legitimacy than an effective quality disclosure signal.

In summary, CSRA is a component of two distinct mechanisms that could have opposite effects. On the one hand, if CSRA functions as a signaling mechanism, it implies that assurance guarantees the quality of information (credibility and relevance), so such information enhances users' confidence. On the other hand, if management strategically captures or controls information and assurance providers, it can use CSRA as a legitimacy tool, even if doing so means misleading stakeholders. In this case, CSRA is not beneficial to the intended users. To go further, we next discuss the expected benefits of CSRA in contrast with factors that limit professional accountants' contribution and lead to an expectation gap.

\section{CSRA: (New) challenges for professional accountants?}

\section{The expected benefits of CSRA}

CSRA is expected to result in higher-quality reporting (Ballou et al., 2018; Casey \& Grenier, 2015; Kolk \& Perego, 20l0; Simnett, Vanstraelen, \& Fong Chua, 2009). For example, Ballou et al. (2018, p. 169) found that CSRA, especially when provided by professional accountants, improves the quality of CSR reports "by identifying inaccuracies in prior reports and improvements to definitions, scopes, and methodologies that require restatements for comparability." CSRA is expected to assure intended users that they can rely on the disclosed information to make decisions with confidence. In other words, CSR information should be deemed as more relevant, that is, as more useful for decision-making and as more trustworthy when it is assured by external and independent third parties than when it is not assured. In the case of the Carbon Disclosure Project, found that the market penalizes firms with high greenhouse gas ( $\mathrm{GHG}$ ) emissions, but they also found that this negative effect on the market is mitigated by the presence of CSRA. These findings suggest that while GHG disclosures signal risks and potential liabilities that investors take into consideration when assessing a firm, assurance increases the quality of these disclosures, which is beneficial for moderating the negative effect of GHG emissions. In addition, found that the moderating effect of CSRA on the market reaction is greater when assurance is provided by a member of the accounting profession.

Hummel et al. (2019) noted that the question on who is to provide the assurance is crucial, as the assurance provider charges a considerable amount of money to conduct CSRA. While companies can choose from a large range of providers, a large majority of them mandate professional accountants to assure their CSR reports (Larrinaga et al., 20 I 8). There are two main reasons for this: (I) professional accountants have legitimacy in the eyes of key audiences (O'Dwyer, 20II) and (2) the quality of CSRA is expected to improve with the provision of assurance services by professional accountants instead of consultants (Fernandez-Feijoo, Romero, \& Ruiz, 20 I 2; Hummel et al., 2019; Zorio et al., 2013). The brand name and reputational capital of professional accountants positively influence the quality of assurance engagement (Fernandez-Feijoo et al., 2012; Perego \& Kolk, 20 I2). In addition, because they are subject to the principle of independence and the code of professional ethics, professional accountants conduct their CSRA mission under professional standards, which is assumed to increase both the quality of their assurance work (Huggins, Green, \& Simnett, 20II) and the cost of assurance engagement (Simnett et al., 2009). As a result, the signal given by CSRA is more likely greater when assurance is provided by professional accountants rather than by other assurance providers (Hodge et al., 2009; Pflugrath et al., 20 I I).

In addition, as noted by Martinez-Ferrero and Garcia-Sanchez (20 I 6), the level of assurance is influenced by the reputation and industry expertise of the assurance providers. Given the uncertainties and risks inherent in CSR data, accounting professionals are expected to adopt a more cautious and conservative approach to assurance, which implies an inclination to issue a low level of assurance (Janggu, Darusi, Sawani, \& Zain, 20 I 3; O'Dwyer \& Owen, 2005; Perego \& Kolk, 20I2). Sustainability experts, in contrast, are assumed to adopt a more evaluative approach and generally issue higher assurance levels (O'Dwyer \& Owen, 2005). Stakeholders (such as investors) thereby declare greater confidence in sustainability reports when the level of assurance stated is reasonable (Hodge et al., 2009). Finally, as highlighted by O'Dwyer and Owen (2005), Pflugrath et al. (20 I I) and MartinezFerrero and Garcia-Sanchez (2016), the benefits of CSRA for intended users are found to vary depending on the properties of the CSRA, such as the type of assurance provider (professional accountants versus sustainability consultants or experts) and the level of the assurance statement (reasonable versus limited).

\section{The existence of an expectation gap}

Many studies have found evidence of an expectation gap in financial audits (see, for example, Epstein \& Geiger, 1994; Gay, Schelluch, \& Baines, 1998; Humphrey, Moizer, \& Turley, 1993; McEnroe \& Martens, 200 I). An expectation gap exists when different beliefs 
on the levels of performance (effectiveness) of assurance are held by different stakeholders (i.e., firms, assurers, and users). According to Monroe and Woodliff (1993), an audit expectation gap arises when auditors and the public hold different beliefs about the duties and responsibilities assumed by auditors and the messages conveyed by audit statements. More generally, there are various reasons for expectation gaps: unreasonable expectations placed on assurance practitioners, uncertainties associated with the purpose and effects of assurance, misunderstandings about the assurance report, etc. Similar to financial audits, an expectation gap exists with regard to CSRA (Green \& Li, 20 I2; Hodge et al., 2009; Wong \& Millington, 20 I4).

According to Goicoechea et al. (2019), there are several challenges that limit the contribution of assurance providers and lead to an expectation gap. Some of them are methodological and result from a lack of standardization. First, even if many institutions (such as the Global Reporting Initiative) have established guidelines for CSR reporting, there are no generally accepted reporting criteria, while stakeholders demand the same guarantees for CSR reporting as they have for traditional financial information. For example, in 2013, the International Integrated Reporting Council (IIRC) launched a principle-based framework for integrated reporting with both financial and nonfinancial information. However, despite this framework, the question of integrated reports assurance still remains (Briem \& Wald, 20I8). Since integrated reports cover a substantial amount of CSR information in addition to financial information, the auditing of only the financial parts of these reports without considering the CSR parts damages the perceived credibility of the disclosed CSR information. Second, there is a lack of specific guidance relating to CSRA itself. This has resulted in variation in the subject matter of assurance engagements as well as in a wide variety of and ambiguity in the assurance statements (Janggu et al., 2013). ${ }^{8}$ Therefore, users misunderstand the conclusions provided in assurance statements. For example, there is debate over the level of assurance that professional auditors should or can provide regarding CSR information. According to Goicoechea et al. (2019), the framework of reasonable and limited assurance is not suitable, specifically in the case of integrated reporting. As a consequence, users seem unable to distinguish between CSR assurance statements with a high level and those with a limited level (Roebuck, Simnett, \& Ho, 2000). In addition, according to Boiral, Heras-Saizarbitoria, Brotherton, \& Bernard (2019), assurance providers use confusing technical language, and this jargon can mask the scope of assurance.

There are several other obstacles that limit the contribution of professional accountants as assurance providers and negatively affect the quality of CSRA. Professional accountants appear unfamiliar with CSR issues because of a weakness in

\footnotetext{
8. However, some authors document that the CSRA market is dominated by Big 4 firms and that this tends to increase the homogeneity of assurance statements (Gürtürk \& Hahn, 2015; Manetti \& Becatti, 2009; Martinez-Ferrero \& Garcia-Sanchez, 2016).
}

accounting education regarding the ethical and social aspects of management (Chiang, 2006; Chiang \& Northcott, 2012; Dixon, Mousa, \& Woodhead, 2004; Williams \& Elson, 2010). The education and experience of professional accountants makes them specialists in accounting and auditing, but they do not have sufficient skills, knowledge, and training in CSR issues. Consequently, this may lead accountants to ignore environmental matters and risks in audit planning if there are no disclosures on such topics in the financial report. This is consistent with Boiral, Heras-Saizarbitoria, Brotherton, \& Bernard (2019), according to whom assurance providers conduct a symbolic and superficial rather than an in-depth verification of the quality and transparency of CSR reports.

The independence of assurance providers from the firm carrying out the CSRA may also be questionable (Dixon et al., 2004). Some authors argue that professional accountants are incapable of thinking critically when assessing managerial decisions and practices, highlighting the existence of managerial capture (Hummel et al., 20 I 9; Michelon et al., 20 I 5). In addition, the independence of professional accountants is questionable given the commercial relationship between auditors and firms (Boiral, HerasSaizarbitoria, \& Brotherton, 2019; Boiral, Heras-Saizarbitoria, Brotherton, \& Bernard, 2019; Perego \& Kolk, 20I2). In some circumstances, assurance providers are accused of 'hijacking', that is, of serving the commercial interests of the managers rather than the broader public interest (Smith et al., 201 I). According to Boiral, Heras-Saizarbitoria, Brotherton, \& Bernard (2019), commercial pressures are most acute when assurance providers depend on clients for their economic survival, and this is often the case for small providers.

To summarize, this literature review reveals contrasting evidence of the effectiveness of CSRA. On the one hand, some findings support the idea that CSRA is an effective signal that benefits stakeholders. On the other hand, as suggested by legitimacy theory, CSRA suffers from an expectation gap reflecting stakeholders' suspicion of its effectiveness. However, in view of the major role that professional accountants appear to play in the quality and (in)effectiveness of CSRA, it is very surprising to note that their opinions about CSRA to date have been highly ignored in studies (Boiral, Heras-Saizarbitoria, \& Brotherton, 2019; Boiral, Heras-Saizarbitoria, Brotherton, \& Bernard, 2019). To fill this gap and to further disentangle the two explanations of CSRA based on the signaling and legitimacy theories, it is crucial to conduct an extensive investigation on what professional accountants themselves perceive and think about CSRA and its effectiveness.

\section{Research method}

In line with Hodge et al. (2009), we use a questionnaire survey involving a between-subjects experimental design. This experimental questionnaire serves to satisfy two main objectives. First, through a quantitative approach, we investigate whether 
the practice of CSRA, as well as the type of assurance provider and the level of assurance, impacts the perceptions of professional accountants with regard to the relevance of CSR information and confidence in this information. Indeed, if CSRA is an effective signal on the quality of information, the assured CSR information should be perceived as more relevant, that is, as more useful for decision-making, as well as more trustworthy than CSR information reported without assurance. Second, by using open questions and qualitative answers, we gain a more in-depth understanding of what professional accountants as assurance providers think about the effectiveness of CSRA.

\section{Experimental groups and participants}

As shown in Table I, this study involves five groups: one group receives no assurance (the control group), and the other four groups receive an assurance statement varying according to the type of provider (an accounting or a non-accounting provider) and the level of assurance (reasonable or moderate).

The participants are 104 French professional accountants in Big 4 and non-Big 4 audit firms. ${ }^{9}$ They were contacted by email: their electronic addresses were obtained from the list of the members of the French National Institute of Auditors. The participants were randomly assigned to the five groups previously described. Table 2 shows the number of participants in each group and summarizes their main characteristics.

The average proportion of men is $85 \%$, and participants have an average of 19.81 years of experience. We used a nonparametric test (Kruskal-Wallis test) to compare the characteristics of the groups of participants. The Khi-2 statistics indicate that the distributions of the different groups are statistically similar in terms of gender and professional experience. This guarantees that any significant difference in the responses between groups is not due to differences in the characteristics of the participants but rather due to manipulation of the information provided to the participants in the groups.

\section{Set of documents and questionnaire}

The professional accountants received a cover letter and a set of documents concerning the company Alpha. They had to read these documents before answering the questionnaire. The set of documents composed of consolidated financial statements for Alpha in a given year. ${ }^{10}$ The financial information was released in the balance sheet and the income statement. The professional accountants also received an accompanying financial audit statement carrying a 'reasonable assurance.' Second, the professional accountants received CSR

\footnotetext{
9. Informed consent was obtained from all individual participants included in the study. The consent is in accordance with the ethical standards of the institutional and/or national research committee.

10. The consolidated financial statements were presented in accordance with IFRS.
}

Table I. Treatment groups

\begin{tabular}{ll}
\hline Groups & Treatment \\
\hline 1 & Absence of CSRA \\
2 & CSRA statement provided by a professional accountant \\
3 & CSRA statement provided by a non-professional accountant \\
& (sustainability expert) \\
4 & CSRA statement attesting a moderate assurance \\
5 & CSRA statement attesting a reasonable assurance \\
\hline
\end{tabular}

CSRA, corporate social responsibility assurance.

Table 2. Number of participants and characteristics

\begin{tabular}{lccc}
\hline Groups & $\begin{array}{c}\text { Number of } \\
\text { participants }\end{array}$ & $\begin{array}{c}\text { Proportion of men } \\
\text { in \% (mean rank) }\end{array}$ & $\begin{array}{c}\text { Professional experience } \\
\text { in years (mean rank) }\end{array}$ \\
\hline 1 & 33 & $76(49.03)$ & $24.94(69.47)$ \\
2 & 18 & $83(52.67)$ & $20(53.44)$ \\
3 & 18 & $89(55.61)$ & $21.11(58.08)$ \\
4 & 18 & $94(58.56)$ & $15.06(39.36)$ \\
5 & 17 & $82(52.15)$ & $17.94(47.76)$ \\
Total & 104 & 85 & 19.81 \\
Khi-2 & & $2.576(0.765)$ & $9.435(0.093)$ \\
(Significance & & & \\
level) & &
\end{tabular}

information. Three categories of CSR information were provided: (I) social information (e.g., the gender mix of employees), (2) environmental information (e.g., the amount of carbon emissions, in tons), and (3) information concerning community involvement (e.g., disclosure of donations to a group of selected charities). Finally, the CSR assurance statement was provided (Groups 2, 3, 4, 5), except for the group of participants without CSRA (Group I). Group I was the control group, since this allowed a comparison with the experimental groups in which CSRA was present. All participants were informed that CSR assurance was required for the company.

The questionnaire was administered in late 2015 through an electronic platform (Survey Monkey) and was divided into three parts. The first part contained questions collecting demographic information (such as age, gender, and years of professional experience). In the second part of the questionnaire, accountants were asked (via closed questions) to specify (I) the relevance of the information and (2) the confidence they had in the information to assess the performance of Alpha.The accountants ranked the importance of each item on a five-point Likert scale. In the third part of the questionnaire, the professional accountants were invited to explain what they think about the effectiveness of CSRA (via open questions). This part was absent in the case of the control group (without CSRA).

\section{Quantitative results}

\section{Descriptive statistics}

We asked respondents to score the relevance of the information and the confidence in this information to assess the global 
Table 3. Descriptive statistics for relevance of information

The respondents answer on a Likert scale whether the information is relevant for assessing the global performance of the company: [I = strongly disagree; 2 = disagree, $3=$ neutral; 4 = agree; 5 = strongly agree $]$

Group I = without assurance; Groups 2 to 5 = with assurance (Group 2 = assurance provided by a professional accountant; Group $3=$ assurance provided by a sustainable expert; Group 4 = assurance with a moderate level; Group 5 = assurance with a reasonable level)

Panel A: Mean, (standard deviation) and [median]

\begin{tabular}{|c|c|c|c|c|c|c|c|}
\hline Nature of information & & Group I & Group 2 & Group 3 & Group 4 & Group 5 & Overall Groups 2 to 5 \\
\hline \multirow[t]{2}{*}{ Financial and CSR information } & Financial & $\begin{array}{c}4.18 \\
(1.044) \\
{[4.37]} \\
n=33\end{array}$ & $\begin{array}{c}4.78 \\
(0.548) \\
{[4.82]} \\
n=18\end{array}$ & $\begin{array}{c}4.44 \\
(0.922) \\
{[4.60]} \\
n=18\end{array}$ & $\begin{array}{c}4.78 \\
(0.528) \\
{[4.78]} \\
n=18\end{array}$ & $\begin{array}{c}4.59 \\
(0.870) \\
{[4.73]} \\
n=17\end{array}$ & $\begin{array}{c}4.65 \\
(0.719) \\
{[4.74]} \\
n=71\end{array}$ \\
\hline & CSR & $\begin{array}{c}3.73 \\
(1.126) \\
{[3.65]} \\
n=33\end{array}$ & $\begin{array}{c}3.78 \\
(0.943) \\
{[3.83]} \\
n=18\end{array}$ & $\begin{array}{c}5.56 \\
(0.984) \\
{[3.50]} \\
n=18\end{array}$ & $\begin{array}{c}4.06 \\
(1.110) \\
{[4.23]} \\
n=18\end{array}$ & $\begin{array}{c}3.82 \\
(0.951) \\
{[3.82]} \\
n=17\end{array}$ & $\begin{array}{c}3.80 \\
(0.995) \\
{[3.84]} \\
n=71\end{array}$ \\
\hline \multirow[t]{3}{*}{$\begin{array}{l}\text { Decomposition of CSR } \\
\text { information }\end{array}$} & Social & $\begin{array}{c}3.48 \\
(1.149) \\
{[3.50]} \\
n=33\end{array}$ & $\begin{array}{c}3.56 \\
(1.097) \\
{[3.60]} \\
n=18\end{array}$ & $\begin{array}{c}3.28 \\
(1.179) \\
{[3.42]} \\
n=18\end{array}$ & $\begin{array}{c}3.83 \\
(1.200) \\
{[4.08]} \\
n=18\end{array}$ & $\begin{array}{c}3.76 \\
(0.903) \\
{[3.83]} \\
n=17\end{array}$ & $\begin{array}{c}3.61 \\
(1.102) \\
{[3.72]} \\
n=71\end{array}$ \\
\hline & Environmental & $\begin{array}{c}2.72 \\
(1.227) \\
{[2.78]} \\
n=18\end{array}$ & $\begin{array}{c}3.42 \\
(1.200) \\
{[3.50]} \\
n=33\end{array}$ & $\begin{array}{c}3.11 \\
(1.079) \\
{[3.00]} \\
n=18\end{array}$ & $\begin{array}{c}3.50 \\
(1.200) \\
{[3.60]} \\
n=18\end{array}$ & $\begin{array}{c}3.94 \\
(0.966) \\
{[4.07]} \\
n=17\end{array}$ & $\begin{array}{c}3.31 \\
(1.190) \\
{[3.41]} \\
n=71\end{array}$ \\
\hline & $\begin{array}{l}\text { Community } \\
\text { involvement }\end{array}$ & $\begin{array}{c}2.56 \\
(1.097) \\
{[2.60]} \\
n=18\end{array}$ & $\begin{array}{c}3.30 \\
(1.237) \\
{[3.39]} \\
n=33\end{array}$ & $\begin{array}{c}2.83 \\
(1.150) \\
{[2.80]} \\
n=18\end{array}$ & $\begin{array}{c}3.72 \\
(1.179) \\
{[3.80]} \\
n=18\end{array}$ & $\begin{array}{c}3.47 \\
(1.007) \\
{[3.62]} \\
n=17\end{array}$ & $\begin{array}{c}3.14 \\
(1.187) \\
{[3.24]} \\
n=71\end{array}$ \\
\hline
\end{tabular}

Panel B:Test of mean responses questions $>3$

Difference from 3; Df; $t$-value; $p$-value

\begin{tabular}{|c|c|c|c|c|c|c|c|}
\hline \multirow{2}{*}{\multicolumn{2}{|c|}{ Nature of information }} & & & & & & \\
\hline & & Group I & Group 2 & Group 3 & Group 4 & Group 5 & Overall Groups 2 to 5 \\
\hline \multirow[t]{8}{*}{ Financial and CSR information } & Financial & 1.182 & 1.778 & 1.444 & 1.778 & 1.588 & 1.548 \\
\hline & & 32 & 17 & 17 & 17 & 16 & 70 \\
\hline & & 6.500 & 13.756 & 6.648 & 17.631 & 7.525 & 19.309 \\
\hline & & 0.000 & 0.000 & 0.000 & 0.000 & 0.000 & 0.000 \\
\hline & CSR & 0.727 & 0.778 & 0.556 & 1.056 & 0.824 & 0.803 \\
\hline & & 32 & 17 & 17 & 17 & 16 & 70 \\
\hline & & 3.712 & 3.500 & 2.397 & 4.035 & 3.570 & 6.802 \\
\hline & & 0.001 & 0.003 & 0.028 & 0.001 & 0.003 & 0.000 \\
\hline \multirow[t]{12}{*}{ Decomposition of CSR information } & Social & 0.485 & 0.556 & 0.278 & 0.833 & 0.756 & 0.606 \\
\hline & & 32 & 17 & 17 & 17 & 16 & 70 \\
\hline & & 2.424 & 2.149 & 1.000 & 2.945 & 3.490 & 4.632 \\
\hline & & 0.021 & 0.046 & 0.331 & 0.009 & 0.003 & 0.032 \\
\hline & Environmental & -0.278 & 0.424 & 0.111 & 0.500 & 0.941 & 0.310 \\
\hline & & 17 & 32 & 17 & 17 & 16 & 70 \\
\hline & & -0.960 & 2.031 & 0.437 & 2.945 & 4.016 & 2.193 \\
\hline & & 0.350 & 0.424 & 0.668 & 0.095 & 0.001 & 0.032 \\
\hline & Community & -0.444 & 0.303 & -0.167 & 0.722 & $0.47 \mid$ & 0.141 \\
\hline & involvement & 17 & 32 & 17 & 17 & 16 & 70 \\
\hline & & -1.719 & 1.407 & -0.615 & 2.600 & 1.926 & 1.000 \\
\hline & & 0.104 & 0.169 & 0.547 & 0.019 & 0.072 & 0.321 \\
\hline
\end{tabular}

$n=$ number of observations.

CSR, corporate social responsibility. 
Table 4. Descriptive statistics for confidence in information Respondents answer on a Likert scale whether they are confident in the information for assessing the global performance of the company: [ I = strongly disagree; 2 = disagree, 3 = neutral; 4 = agree; 5 = strongly agree]

Group I = without assurance; Groups 2 to 5 = with assurance (Group 2 = assurance provided by a professional accountant; Group $3=$ assurance provided by a sustainable expert; Group $4=$ assurance with a moderate level; Group 5 = assurance with a reasonable level)

Panel A: Mean, (standard deviation) and [median]

\begin{tabular}{|c|c|c|c|c|c|c|c|}
\hline Nature of information & & Group I & Group 2 & Group 3 & Group 4 & Group 5 & Overall Groups 2 to 5 \\
\hline \multirow[t]{2}{*}{ Financial and CSR information } & Financial & $\begin{array}{c}4.03 \\
(0.951) \\
{[4.13]} \\
n=33\end{array}$ & $\begin{array}{c}4.11 \\
(0.583) \\
{[4.13]} \\
n=18\end{array}$ & $\begin{array}{c}4.11 \\
(0.583) \\
{[4.13]} \\
n=18\end{array}$ & $\begin{array}{c}4.17 \\
(0.618) \\
{[4.19]} \\
n=18\end{array}$ & $\begin{array}{c}3.94 \\
(0.659) \\
{[3.93]} \\
n=17\end{array}$ & $\begin{array}{c}4.08 \\
(0.603) \\
{[4.10]} \\
n=71\end{array}$ \\
\hline & CSR & $\begin{array}{c}3.52 \\
(1.004) \\
{[3.56]} \\
n=33\end{array}$ & $\begin{array}{c}3.67 \\
(0.767) \\
{[3.73]} \\
n=18\end{array}$ & $\begin{array}{c}3.62 \\
(0.502) \\
{[3.61]} \\
n=18\end{array}$ & $\begin{array}{c}3.56 \\
(0.784) \\
{[3.60]} \\
n=18\end{array}$ & $\begin{array}{c}3.76 \\
(0.562) \\
{[3.75]} \\
n=17\end{array}$ & $\begin{array}{c}3.65 \\
(0.657) \\
{[3.67]} \\
n=71\end{array}$ \\
\hline \multirow[t]{3}{*}{$\begin{array}{l}\text { Decomposition of CSR } \\
\text { information }\end{array}$} & Social & $\begin{array}{c}3.33 \\
(0.990) \\
{[3.40]} \\
n=33\end{array}$ & $\begin{array}{c}3.44 \\
(0.784) \\
{[3.47]} \\
n=18\end{array}$ & $\begin{array}{c}3.39 \\
(0.502) \\
{[3.39]} \\
n=18\end{array}$ & $\begin{array}{c}3.28 \\
(0.752) \\
{[3.33]} \\
n=18\end{array}$ & $\begin{array}{c}3.53 \\
(0.624) \\
{[3.50]} \\
n=17\end{array}$ & $\begin{array}{c}3.41 \\
(0.667) \\
{[3.67]} \\
n=71\end{array}$ \\
\hline & Environmental & $\begin{array}{c}2.94 \\
(0.966) \\
{[3.04]} \\
n=33\end{array}$ & $\begin{array}{c}3.33 \\
(0.767) \\
{[3.33]} \\
n=18\end{array}$ & $\begin{array}{c}3.11 \\
(0.583) \\
{[3.13]} \\
n=18\end{array}$ & $\begin{array}{c}3.06 \\
(0.725) \\
{[3.07]} \\
n=18\end{array}$ & $\begin{array}{c}3.29 \\
(0.588) \\
{[3.31]} \\
n=17\end{array}$ & $\begin{array}{c}3.20 \\
(0.668) \\
{[3.21]} \\
n=71\end{array}$ \\
\hline & $\begin{array}{l}\text { Community } \\
\text { involvement }\end{array}$ & $\begin{array}{c}2.97 \\
(1.015) \\
{[3.08]} \\
n=33\end{array}$ & $\begin{array}{c}3.06 \\
(1.056) \\
{[3.09]} \\
n=18\end{array}$ & $\begin{array}{c}3.00 \\
(0.594) \\
{[3.00]} \\
n=18\end{array}$ & $\begin{array}{c}3.06 \\
(0.802) \\
{[3.08]} \\
n=18\end{array}$ & $\begin{array}{c}3.29 \\
(0.588) \\
{[3.31]} \\
n=17\end{array}$ & $\begin{array}{c}3.10 \\
(0.777) \\
{[3.13]} \\
n=71\end{array}$ \\
\hline
\end{tabular}

Panel B:Test of mean responses questions $>3$

Difference from 3; Df; $t$-value; $p$-value

\begin{tabular}{|c|c|c|c|c|c|c|c|}
\hline \multirow{2}{*}{\multicolumn{2}{|c|}{ Nature of information }} & \multirow[b]{2}{*}{ Group I } & \multirow[b]{2}{*}{ Group 2} & \multirow[b]{2}{*}{ Group 3} & \multirow[b]{2}{*}{ Group 4} & \multirow[b]{2}{*}{ Group 5} & \multirow[b]{2}{*}{ Overall Groups 2 to 5} \\
\hline & & & & & & & \\
\hline \multirow[t]{8}{*}{ Financial and CSR information } & Financial & 1.030 & $||||$. & $||||$. & 1.167 & 0.941 & 1.085 \\
\hline & & 32 & 17 & 17 & 17 & 16 & 70 \\
\hline & & 6.220 & 8.086 & 8.086 & 8.005 & 5.892 & 15.143 \\
\hline & & 0.000 & 0.000 & 0.000 & 0.000 & 0.000 & 0.000 \\
\hline & CSR & 0.515 & 0.667 & 0.611 & 0.556 & 0.756 & 0.648 \\
\hline & & 32 & 17 & 17 & 17 & 16 & 70 \\
\hline & & 2.948 & 3.688 & 5.169 & 3.004 & 5.607 & 8.312 \\
\hline & & 0.006 & 0.002 & 0.000 & 0.008 & 0.000 & 0.000 \\
\hline \multirow[t]{12}{*}{ Decomposition of CSR information } & Social & 0.333 & 0.444 & 0.389 & 0.278 & 0.529 & 0.408 \\
\hline & & 32 & 17 & 17 & 17 & 16 & 70 \\
\hline & & 1.935 & 2.406 & 3.289 & 1.567 & 3.497 & 5.159 \\
\hline & & 0.062 & 0.028 & 0.004 & 0.135 & 0.003 & 0.000 \\
\hline & Environmental & -0.61 & 0.333 & 0.111 & 0.056 & 0.294 & 0.197 \\
\hline & & 32 & 17 & 17 & 17 & 16 & 70 \\
\hline & & -0.360 & 1.844 & 0.809 & 0.325 & 2.063 & 2.487 \\
\hline & & 0.721 & 0.083 & 0.430 & 0.749 & 0.056 & 0.015 \\
\hline & Community & -0.030 & 0.056 & 0.000 & 0.056 & 0.294 & 0.099 \\
\hline & involvement & 32 & 17 & 17 & 17 & 16 & 70 \\
\hline & & $-0.17 \mid$ & 0.223 & 0.000 & 0.294 & 2.063 & 1.068 \\
\hline & & 0.865 & 0.826 & 1.000 & 0.772 & 0.056 & 0.289 \\
\hline
\end{tabular}

$n=$ number of observations.

CSR, corporate social responsibility. 
performance of Alpha on Likert scales with five points (value of 3 is the neutral opinion). Tables 3 and 4 summarize the descriptive statistics (Panel A) and compare the means with the value of 3 as a neutral opinion (Panel B) for the two dependent variables.

In Table 3, the mean responses to the relevance question of 4.65 (financial information) and 3.80 (CSR information) with CSRA (resp. 4.18 and 3.73 without CSRA) are significantly above 3. This comparison indicates that professional accountants find that both the financial information and the CSR information are relevant to assessing the global performance of Alpha even if we can note a preference for financial information (the means of the relevance scores of the financial information are systematically above the means of the relevance scores of the CSR information). When the CSR information is decomposed, it appears that professional accountants are rather neutral regarding the relevance of the community involvement information: the mean responses of 3.14 for CSRA (overall Groups 2 to 5) and 2.56 without CSRA (Group I) are not significantly different from 3.

Table 4 reveals the same pattern in the professional accountants' confidence in the information. The mean responses to the confidence in the financial and CSR information are 4.08 and 3.65, respectively, with CSRA (overall Groups 2 to 5) versus 4.03 and 3.52, respectively, without CSRA (Group I). As previously seen, the professional accountants' confidence in the information concerning community involvement is rather neutral.

\section{The impact of CSRA on the perceived relevance of the information and confidence in this information}

In Table 5, we investigate whether CSRA positively influences the perceptions of professional accountants captured by the perceived relevance of the information and the confidence in this information. We use ANOVA (one-way) to test whether the two dependent variables (the relevance of CSR information in Panel A and confidence in this information in Panel B) are differently scored by participants without CSRA and with CSRA.

This analysis indicates that CSRA has no impact on the perceived relevance of the information (Panel A); only the relevance of the environmental and community involvement information increases with CSRA provided by sustainable experts (Group I vs. Group 3). The same pattern is observed for professional accountants' confidence in CSR information (Panel B): the presence of CSRA does not increase the participants' level of confidence in CSR information.

We also investigate whether the type of assurance provider (professional accountants or sustainability experts) and the level of assurance (reasonable or limited) impact the perceptions of professional accountants. The results are summarized in Table 6: dependent variables (the relevance of CSR information in Panel A and confidence in this information in Panel B) are compared between Groups 2 and 3 and Groups 4 and 5.

We note that neither the type of assurance providers nor the level of assurance changes the perceptions of the professional accountants with regard to the relevance of the CSR information and the confidence in this information.

To sum up, given the French context, where CSRA has been mandatory since the adoption of the Grenelle 2 law and where professional accountants have been officially recognized as competent in carrying out such assurance engagements, we might have expected to find that the professional accountants would recognize CSRA as effective. However, we find that they are not convinced by the benefits of CSRA or, in other terms, by the increase in CSR relevance of the information and confidence in this information due to the assurance of CSR reports.

\section{Qualitative results}

\section{Data coding}

To better understand professional accountants' perceptions of CSRA, we chose to use open questions to collect qualitative answers. This seems appropriate for developing our understanding of CSRA, especially concerning the complexities underlying this practice (Edmondson \& McManus, 2007). In the questionnaire, we asked respondents (except for Group I) the following open questions: "What do you think about the effectiveness of CSRA? Why?"

We used a manual thematic analysis (Miles \& Huberman, 1994) with the main objective of identifying and delimiting categories of topics advanced by professional accountants to justify their perceptions of the effectiveness of CSRA. To generate those categories, we drew upon an inductive approach (Corbin \& Strauss, 2008; Gioia, Corley, \& Hamilton, 2012), and we also leaned on the literature review. Our methodology is quite similar to that described by Cisneros and Deschamps (2015) and Laszczuk and Mayer (2020). Our analysis comprised three main steps, which consisted of moving back and forth between raw data and the literature (developed in Section 2). We reviewed our raw data (first step) to generate a list of topics on which the experiment participants focused significant attention (second step). We then gathered similar topics into general categories or themes of attention (third step). These categories reflect a set of issues that received significant attention from the professional accountants. For example, after reading the qualitative answers, we identified a list of three main topics related to the nature of the data: difficulties in understanding and analyzing CSR data because of complexity, difficulties in measuring CSR data because it is too subjective 
Table 5. ANOVA one-way; CSRA versus no CSRA

Panel A: Dependent variable: Relevance of information

\begin{tabular}{|c|c|c|c|c|c|c|c|}
\hline Comparison of groups & & & Sum of square & Df. & Mean square & $F$ & Sign. \\
\hline \multirow[t]{12}{*}{ Group I / Group 2} & \multirow[t]{3}{*}{ CSR information } & Between groups & 0.030 & । & 0.030 & \multirow[t]{3}{*}{0.026} & \multirow[t]{3}{*}{0.872} \\
\hline & & Within groups & 55.657 & 49 & 1.136 & & \\
\hline & & Total & 55.568 & 50 & & & \\
\hline & \multirow[t]{3}{*}{ Social information } & Between groups & 0.058 & I & 0.058 & \multirow[t]{3}{*}{0.046} & \multirow[t]{3}{*}{0.832} \\
\hline & & Within groups & 62.687 & 49 & 1.279 & & \\
\hline & & Total & 62.745 & 50 & & & \\
\hline & \multirow{3}{*}{$\begin{array}{l}\text { Environmental } \\
\text { information }\end{array}$} & Between groups & 1.142 & I & 1.142 & \multirow[t]{3}{*}{0.850} & \multirow[t]{3}{*}{0.361} \\
\hline & & Within groups & 65.838 & 49 & 1.344 & & \\
\hline & & Total & 66.980 & 50 & & & \\
\hline & \multirow{3}{*}{$\begin{array}{l}\text { Information concerning } \\
\text { community involvement }\end{array}$} & Between groups & 2.570 & | & 2.570 & \multirow[t]{3}{*}{1.762} & \multirow[t]{3}{*}{0.191} \\
\hline & & Within groups & 71.470 & 49 & 1.459 & & \\
\hline & & Total & 74.039 & 50 & & & \\
\hline \multirow[t]{12}{*}{ Group I / Group 3} & \multirow[t]{3}{*}{ CSR information } & Between groups & 0.343 & I & 0.343 & 0.295 & 0.589 \\
\hline & & Within groups & 56.990 & 49 & 1.162 & & \\
\hline & & Total & 57.333 & 50 & & & \\
\hline & Social information & Between groups & 0.499 & I & 0.499 & 0.372 & 0.545 \\
\hline & & Within groups & 65.854 & 49 & 1.344 & & \\
\hline & & Total & 66.353 & 50 & & & \\
\hline & Environmental & Between groups & 5.740 & I & 5.740 & 3.924 & 0.053 \\
\hline & information & Within groups & 71.672 & 49 & 1.463 & & \\
\hline & & Total & 77.412 & 50 & & & \\
\hline & Information concerning & Between groups & 6.507 & I & 6.507 & 4.594 & 0.037 \\
\hline & community involvement & Within groups & 69.414 & 49 & 1.417 & & \\
\hline & & Total & 75.922 & 50 & & & \\
\hline Group I / Group 4 & CSR information & Between groups & 0.835 & | & 0.835 & 0.646 & 0.420 \\
\hline & & Within groups & 60.545 & 48 & $1.26 \mid$ & & \\
\hline & & Total & 61.380 & 49 & & & \\
\hline & Social information & Between groups & 0.879 & I & 0.879 & 0.646 & 0.426 \\
\hline & & Within groups & 65.301 & 48 & 1.360 & & \\
\hline & & Total & 66.180 & 49 & & & \\
\hline & Environmental & Between groups & 0.002 & I & 0.002 & 0.001 & 0.972 \\
\hline & information & Within groups & 68.178 & 48 & 1.420 & & \\
\hline & & Total & 68.180 & 49 & & & \\
\hline & Information concerning & Between groups & 1.328 & I & 1.328 & 0.900 & 0.348 \\
\hline & community involvement & Within groups & 70.852 & 48 & 1.476 & & \\
\hline & & Total & 72.180 & 49 & & & \\
\hline Group I / Group 5 & CSR information & Between groups & 0.104 & I & 0.104 & 0.091 & 0.765 \\
\hline & & Within groups & 55.016 & 48 & 1.146 & & \\
\hline & & Total & 55.120 & 49 & & & \\
\hline & Social information & Between groups & 0.879 & I & 0.879 & 2.359 & 0.131 \\
\hline & & Within groups & 55.301 & 48 & 1.152 & & \\
\hline & & Total & 56.180 & 49 & & & \\
\hline & Environmental & Between groups & 2.998 & I & 2.998 & 2.359 & 0.131 \\
\hline & information & Within groups & 61.002 & 48 & |.27| & & \\
\hline & & Total & 64.000 & 49 & & & \\
\hline & Information concerning & Between groups & 0.315 & I & 0.315 & 0.232 & 0.632 \\
\hline & community involvement & Within groups & 65.205 & 48 & 1.358 & & \\
\hline & & Total & 65.520 & 49 & & & \\
\hline Group I / Groups 2 to 5 & CSR information & Between groups & 1.129 & 1 & 0.129 & 0.119 & 0.730 \\
\hline & & Within groups & 109.785 & 102 & 1.076 & & \\
\hline & & Total & 109.913 & 103 & & & \\
\hline & Social information & Between groups & 0.329 & I & 0.329 & 0.207 & 0.609 \\
\hline & & Within groups & 127.200 & 102 & 1.247 & & \\
\hline & & Total & 127.529 & 103 & & & \\
\hline & Environmental & Between groups & 0.295 & I & 0.295 & 0.207 & 0.650 \\
\hline & information & Within groups & | 45.244 & 102 & 1.424 & & \\
\hline & & Total & 145.538 & 103 & & & \\
\hline & Information concerning & Between groups & 0.593 & I & 0.593 & 0.410 & 0.524 \\
\hline & community involvement & Within groups & |47.56| & 102 & 1.447 & & \\
\hline & & Total & 148.154 & 103 & & & \\
\hline
\end{tabular}


Table 5 (Continued). ANOVA one-way; CSRA versus no CSRA

Panel B: Dependent variable: Confidence in information

\begin{tabular}{|c|c|c|c|c|c|c|c|}
\hline Comparison of groups & & & Sum of square & Df. & Mean square & F & Sign. \\
\hline \multirow[t]{12}{*}{ Group I / Group 2} & \multirow[t]{3}{*}{ CSR information } & Between groups & 0.267 & | & 0.267 & \multirow[t]{3}{*}{0.310} & \multirow[t]{3}{*}{0.580} \\
\hline & & Within groups & 42.242 & 49 & 0.862 & & \\
\hline & & Total & 42.510 & 50 & & & \\
\hline & \multirow[t]{3}{*}{ Social information } & Between groups & 0.144 & | & 0.14 & \multirow[t]{3}{*}{0.169} & \multirow[t]{3}{*}{0.683} \\
\hline & & Within groups & 47.778 & 49 & 0.853 & & \\
\hline & & Total & 41.922 & 50 & & & \\
\hline & \multirow[t]{3}{*}{ Environmental information } & Between groups & 1.807 & I & 1.807 & \multirow[t]{3}{*}{2.221} & \multirow[t]{3}{*}{0.143} \\
\hline & & Within groups & 39.879 & 49 & 0.814 & & \\
\hline & & Total & 41.686 & 50 & & & \\
\hline & Information concerning & Between groups & 0.086 & | & 0.086 & \multirow[t]{3}{*}{0.081} & \multirow[t]{3}{*}{0.777} \\
\hline & \multirow[t]{2}{*}{ community involvement } & Within groups & 51.914 & 49 & 1.059 & & \\
\hline & & Total & 52.000 & 50 & & & \\
\hline \multirow[t]{12}{*}{ Group I / Group 3} & \multirow[t]{3}{*}{ CSR information } & Between groups & 0.107 & I & 0.107 & 0.144 & 0.706 \\
\hline & & Within groups & 36.520 & 49 & 0.745 & & \\
\hline & & Total & 36.624 & 50 & & & \\
\hline & Social information & Between groups & 0.036 & I & 0.036 & 0.049 & 0.825 \\
\hline & & Within groups & 35.611 & 49 & 0.727 & & \\
\hline & & Total & 35.647 & 50 & & & \\
\hline & Environmental information & Between groups & 0.343 & | & 0.343 & 0.472 & 0.495 \\
\hline & & Within groups & 35.657 & 49 & 0.728 & & \\
\hline & & Total & 36.000 & 50 & & & \\
\hline & Information concerning & Between groups & 0.011 & | & 0.011 & 0.013 & 0.908 \\
\hline & community involvement & Within groups & 38.970 & 49 & 0.795 & & \\
\hline & & Total & 38.980 & 50 & & & \\
\hline Group I / Group 4 & CSR information & Between groups & 0.002 & I & 0.002 & 0.003 & 0.960 \\
\hline & & Within groups & 42.478 & 48 & 0.885 & & \\
\hline & & Total & 42.480 & 49 & & & \\
\hline & Social information & Between groups & 0.108 & I & 0.108 & 0.128 & 0.722 \\
\hline & & Within groups & 40.392 & 48 & 0.842 & & \\
\hline & & Total & 40.500 & 49 & & & \\
\hline & Environmental information & Between groups & 0.041 & | & 0.041 & 0.052 & 0.820 \\
\hline & & Within groups & 37.879 & 48 & 0.789 & & \\
\hline & & Total & 37.920 & 49 & & & \\
\hline & Information concerning & Between groups & 0.010 & | & 0.010 & 0.012 & 0.915 \\
\hline & community involvement & Within groups & 42.970 & 48 & 0.895 & & \\
\hline & & Total & 42.980 & 49 & & & \\
\hline Group | / Group 5 & CSR information & Between groups & 0.699 & I & 0.699 & 0.899 & 0.348 \\
\hline & & Within groups & 37.301 & 48 & 0.777 & & \\
\hline & & Total & & 49 & & & \\
\hline & Social information & Between groups & 0.431 & | & 0.431 & 0.551 & 0.461 \\
\hline & & Within groups & 37.569 & 48 & 0.783 & & \\
\hline & & Total & 38.000 & 49 & & & \\
\hline & Environmental information & Between groups & 1.412 & I & 1.412 & 1.914 & 0.173 \\
\hline & & Within groups & 35.408 & 48 & 0.738 & & \\
\hline & & Total & 36.820 & 49 & & & \\
\hline & Information concerning & Between groups & 1.181 & I & 1.181 & 1.472 & 0.231 \\
\hline & community involvement & Within groups & 38.499 & 48 & 0.802 & & \\
\hline & & Total & 39.680 & 49 & & & \\
\hline Group I / & CSR information & Between groups & 0.397 & I & 0.397 & 0.648 & 0.423 \\
\hline Groups 2 to 5 & & Within groups & 62.440 & 102 & 0.612 & & \\
\hline & & Total & 62.837 & 103 & & & \\
\hline & Social information & Between groups & 0.127 & । & 0.127 & 2.08 & 0.650 \\
\hline & & Within groups & 62.488 & 102 & 0.613 & & \\
\hline & & Total & 62.615 & 103 & & & \\
\hline & Environmental information & Between groups & 0.1497 & । & 1.497 & 2.499 & 0.117 \\
\hline & & Within groups & 61.118 & 102 & 0.599 & & \\
\hline & & Total & 62.615 & 103 & & & \\
\hline & Information concerning & Between groups & 0.374 & I & 0.374 & 0.507 & 0.478 \\
\hline & community involvement & Within groups & 75.280 & 102 & 0.738 & & \\
\hline & & Total & 75.654 & 103 & & & \\
\hline
\end{tabular}

CSR, corporate social responsibility; CSRA, corporate social responsibility assurance.

Significant of bold values is $5 \%$. 
Table 6. One-way ANOVA: type of provider and level of assurance

Panel A: Dependent variable: Relevance of information

\begin{tabular}{|c|c|c|c|c|c|c|c|}
\hline Comparison of groups & & & Sum of squares & Df & Mean square & $F$ & Sig \\
\hline \multirow[t]{12}{*}{ Group 2 / Group 3} & CSR information & Between groups & 0.444 & 1 & 0.444 & 0.279 & 0.494 \\
\hline & & Within groups & 31.556 & 34 & 0.928 & & \\
\hline & & Total & 32.000 & 35 & & & \\
\hline & Social information & Between groups & 0.694 & I & 0.694 & 1.020 & 0.320 \\
\hline & & Within groups & 44.056 & 34 & 1.296 & & \\
\hline & & Total & 44.750 & 35 & & & \\
\hline & Environmental information & Between groups & $1.36 \mid$ & I & $|.36|$ & 1.020 & 0.320 \\
\hline & & Within groups & 45.389 & 34 & 1.335 & & \\
\hline & & Total & 46.750 & 35 & & & \\
\hline & Information concerning & Between groups & 0.694 & I & 0.694 & 0.550 & 0.463 \\
\hline & community involvement & Within groups & 42.944 & 34 & 1.263 & & \\
\hline & & Total & 43.639 & 35 & & & \\
\hline \multirow[t]{12}{*}{ Group 4 / Group 5} & CSR information & Between groups & 0.471 & I & $0.47 \mid$ & 0.439 & 0.512 \\
\hline & & Within groups & 35.415 & 33 & 1.073 & & \\
\hline & & Total & 35.886 & 34 & & & \\
\hline & Social information & Between groups & 0.041 & I & 0.41 & 0.036 & 0.850 \\
\hline & & Within groups & 37.559 & 33 & 1.138 & & \\
\hline & & Total & 37.600 & 34 & & & \\
\hline & Environmental information & Between groups & 1.702 & I & 1.702 & 1.424 & 0.241 \\
\hline & & Within groups & 39.441 & 33 & 1.195 & & \\
\hline & & Total & 41.143 & 34 & & & \\
\hline & Information concerning & Between groups & 0.554 & I & 0.554 & 0.458 & 0.503 \\
\hline & community involvement & Within groups & 39.846 & 33 & 1.207 & & \\
\hline & & Total & 40.400 & 34 & & & \\
\hline
\end{tabular}

Panel B: Dependent variable: confidence in information

\begin{tabular}{|c|c|c|c|c|c|c|c|}
\hline \multicolumn{3}{|l|}{ Comparison of groups } & \multirow{2}{*}{$\frac{\text { Sum of squares }}{0.028}$} & \multirow{2}{*}{$\frac{\text { Df }}{1}$} & \multirow{2}{*}{$\frac{\text { Mean square }}{0.028}$} & \multirow{2}{*}{$\frac{F}{0.066}$} & \multirow{2}{*}{$\frac{\text { Sig }}{0.799}$} \\
\hline Group 2 / Group 3 & CSR information & Between groups & & & & & \\
\hline & & Within groups & 14.278 & 34 & 0.420 & & \\
\hline & & Total & 14.306 & 35 & & & \\
\hline & Social information & Between groups & 0.028 & I & 0.028 & 0.064 & 0.802 \\
\hline & & Within groups & 14.722 & 34 & 0.433 & & \\
\hline & & Total & 14.750 & 35 & & & \\
\hline & Environmental information & Between groups & 0.444 & 1 & 0.444 & 0.958 & 0.335 \\
\hline & & Within groups & | 5.778 & 34 & 0.464 & & \\
\hline & & Total & 1 6.222 & 35 & & & \\
\hline & Information concerning & Between groups & 0.028 & I & 0.028 & 0.038 & 0.847 \\
\hline & community involvement & Within groups & 24.944 & 34 & 0.734 & & \\
\hline & & Total & 24.972 & 35 & & & \\
\hline \multirow[t]{12}{*}{ Group 4 / Group 5} & CSR information & Between groups & 0.382 & 1 & 0.382 & 0.814 & 0.373 \\
\hline & & Within groups & 15.503 & 33 & 0.470 & & \\
\hline & & Total & 15.886 & 34 & & & \\
\hline & Social information & Between groups & 0.554 & I & 0.554 & 1.153 & 0.291 \\
\hline & & Within groups & 15.846 & 33 & 0.480 & & \\
\hline & & Total & 16400 & 34 & & & \\
\hline & Environmental information & Between groups & 0.498 & I & 0.498 & 1.134 & 0.295 \\
\hline & & Within groups & 14.474 & 33 & 0.439 & & \\
\hline & & Total & |4.97| & 34 & & & \\
\hline & Information concerning & Between groups & 0.498 & I & 0.498 & 0.997 & 0.325 \\
\hline & community involvement & Within groups & 16.474 & 33 & 0.499 & & \\
\hline & & Total & | 6.97| & 34 & & & \\
\hline
\end{tabular}

CSR, corporate social responsibility. 
and qualitative, difficulties in comparing CSR data between one company and another and over time. These three topics were then clustered into a general theme called 'issues with CSR data.'Table 7 presents the data coding structure. Note that to build our data coding, each researcher independently read and analyzed the raw qualitative data. Several meetings were then organized to compare the data coding done by each researcher to limit possible biases of interpretation.

\section{Professional accountants' perceptions of the effectiveness of CSRA}

The answers of the professional accountants suggest that they are mainly skeptical of the effectiveness of CSRA, even if it is required of firms. Surprisingly, they question their own mission in CSRA. Based on our data coding, we identify four general topics attracting professional accountants' attention. These attentional themes are ( 1 ) issues with CSR data, (2) issues with the content of CSRA statements, (3) the lack of standardization, and (4) the illiteracy regarding CSR issues.

The first point that emerges from the verbatim analysis concerns the characteristics of data to be verified. The complexity of the information appears to be an obstacle for professional accountants. The large amount of information that needs to be verified and the type of data are difficult to use for professional accountants who do not recognize themselves as CSR experts. CSR data are mainly qualitative and textual by nature, and consequently, they are deemed by the interviewees to be unverifiable. As a consequence, "the growing volume of non-financial information makes understanding the company's performance more complex" $(\mathrm{G} 4,6)^{\prime \prime}$; all the more so as "extra-financial information does not provide any information on the company's performance, as the link between performance and well-being is scarcely quantifiable" $(G 5,3)$. Lastly, CSR data appear to be hardly comparable, because they are not homogenous from one company to another and from I year to the next, whereas this should be the case for CSRA to be effective. For professional accountants, this is due in particular to the lack of standard and reference frameworks governing this practice. "Non-financial data provided by companies are often not very reliable because they lack a framework, harmonization: there are few standards to ensure that information is comparable from company to company" (G 5, 12).

As a second point, the qualitative results highlight an issue with the statement content itself because of a lack of relevant conclusions on the quality of information reported by firms and the existence of managerial capture. On the one hand, the assurance statement appears to be very descriptive and

\footnotetext{
11. For each quotation, we indicate between brackets the experimental group and the participant number.
}

does not give information on the strategy of the company. Without giving a relevant informative notice, the report may therefore appear to be ineffective for the reader of the assurance report. A respondent confesses as well that "the CSRA statement is too literary; it does not seem to me concrete enough and does not give a sufficiently informative opinion" $(G 4,8)$. On the other hand, the information contained in the assurance report is given by companies, which may question the confidence that can be had in them and hence the very usefulness of this report for users of the information. Even though the auditors are themselves directly paid by the companies when conducting financial audit missions, they have doubts about the trust that can be granted to the CSRA. The auditors argue first that "the social, societal, environmental and sustainable development issues are in essence given information" $(\mathrm{G} 5,12)$ by companies, which may suggest managerial control in selecting the information disclosed. Second, "while it is impossible to 'silence' the losses of an income statement" $(\mathrm{G} 5,12)$, on the contrary, it is maybe more difficult for auditors to identify breaches in the information given and thus to explicitly require the disclosure of presumed bad news. Thus, the assurance report mainly appears to be an instrument of the company's management. As the report does not reconcile the requirements of the auditors and the managers' predispositions to disclose, it represents an expectation gap. However, the existence of a mismatch between the expectations of the actors may hinder the appreciation of the value of CSRA.

The third point concerns the lack of standardization in the CSR field. According to the interviewees, sustainability indicators are not sufficiently standardized, leading to a lack of harmonization in CSR reporting. This may question the reliability of CSR data and therefore their assurance by an outside party. Compared to "financial data (which) are reported in compliance with well-established standards, environmental data seem much more unclear" $(G 2,3)$. In the same way, procedures to assure CSR data appear insufficiently standardized due to a lack of standard setting in CSRA practice. Even for auditors who are aware of the French regulation of CSRA, "the normative framework for auditing social and environmental data is (considered) too young and not precise enough to be reliable" $(G 2,7)$. This lack of a normative framework generates great variability in the content of assurance statements. Overall, this is likely to call into question the comparability of CSR information and therefore the quality and effectiveness of CSRA.

Finally, the fourth point concerns the 'illiteracy' of professional accountants regarding CSR issues. The auditors acknowledge that they have no experience in CSRA and do not feel to be experts when performing this type of assignment. "Information about CSR is difficult to assess and difficult to check. The professional accountants don't have enough education to analyze these non-financial data" (G5, I I). In addition, 
Table 7. Coding data structure

Representative data (quotes)

G5, 6: How to exploit certain information (for example, women's share of the total workforce, even though studies have shown a correlation between the percentage of women on executive committees and the quality of management)?

G 3, 2: Information on societal commitments is difficult to exploit if one is not an expert on these issues. G3, 9: (Indicators) are difficult to understand for an uninitiated person.

G4, 5: The increase in extra-financial information adds complexity to the understanding of a company's performance.

G4, 6: The growing volume of non-financial information makes understanding the company's performance more complex.

G 3, 2: Societal and environmental data are more difficult to understand because they are not verifiable and quantifiable. G4, 8: Extra-financial information is too literary/ does not seem concrete enough but watered-down. G4, I 3: I think the items I have rated less well are more subjective than the financial items. G5, 3: Extra-financial information does not provide any information on the company's performance, as the link between performance and well-being is scarcely quantifiable. G5, 6: Information on CSR is difficult to assess (quantitative, non-monetary data); it is difficult to verify (e.g., $\mathrm{CO}_{2}$ emissions). G2, I5: I have much more confidence in financial information and the report of the professional accountant than in very subjective information, such as adherence to an environmental program or information related to human rights.

G4, 10: Concerning CSR reporting, we know that it is a presentation intended to construct an image.

I don't take it into account unless something very tangible and verifiable appears.

G4, 3: Social and environmental information is difficult to compare over time. G3, 9: There are indicators with low norms and whose calculations can be very different from one company to another. G5, 5: There are few standards for the information to be comparable from one company to another. G5, 17: Societal and environmental information is not homogeneous and therefore comparable between companies, which leads us to question its relevance, and we therefore focus on the financial statements, which are homogenous.

G 5, 12:The non-financial data provided by companies are often not very reliable because they lack a framework, harmonization: there are few standards to ensure that the information is comparable from company to company.

G4, 8:The CSRA statement is too literary/does not seem to me concrete enough and does not give a sufficiently informative opinion. G5, 9:The societal audit report is only descriptive. It does not seem to me that an audit of the data was carried out by a professional accountant, but only a consistency check and score in relation to the presence of information in the data related to the Commercial Code. G2, 3: The insurance report does not provide information on the company's strategy, so there is nothing of interest. G5, 17:The social audit report is of little relevance, since the data reported by the companies are not standardized and are therefore difficult to compare.

G4, I:The documents produced by people paid by the company are not to be entirely trusted. G5, 12: The social, environmental and sustainable development issues are in essence given information. In case of bad results in this regard, the company is tempted to say nothing (while it is impossible to 'silence' the losses of an income statement) and the control framework of this information seems to me not to be sufficiently armed to this day to force companies to announce social, environmental information ... that could appear unhealthy.

Topics on which experiment participants focused significant Aggregated categories attention

Difficulties in understanding and analyzing CSR data because of complexity

Difficulties in measuring CSR Issues with CSR data data because it is too subjective and qualitative

Difficulties in comparing CSR data between one company and another and over time

Lack of relevant content in CSRA statement (conclusions given are too descriptive and not enough useful)
Issues with the content of CSRA statements
Existence of managerial capture or control by management of the CSR information disclosed questioning the veracity of CSRA statements 
Table 7 (Continued). Coding data structure

Representative data (quotes)

G2, 16: The obligation related to social and environmental disclosure is new and the repository is not yet clear and therefore well applied by companies; hence the lack of confidence. G3, 13: Regarding the social and environmental aspects, it seems to me that these areas are not yet extremely standardized, which can lead to inaccurate data. G5, 5: The extra-financial data provided by companies are often unreliable because of the lack of a harmonization framework. G5, 17: As societal and environmental information is not standardized, it is difficult to form an opinion on these criteria.

G2, 3: Financial data are reported in compliance with well-established standards; environmental data seem much more unclear.

G5, 8: The information is very difficult to check without clear standards. There's no benchmark on social and environmental data, so it's difficult to judge the quality.

G3, I0: CSR data are not strongly regulated indicators and can be calculated differently from company to company and are difficult to understand for a lay person.

G2, 16:The mission of a professional accountant regarding this information has not yet been formalized through an NEP. G4, 3: Judging this information is very difficult without a reference or clear standard. G4, I0: Financial audit procedures are more standardized than those of CSR and therefore more reliable. G2, 7:The normative framework for auditing social and environmental data is too recent and not precise enough to be reliable.

G3, I0:The experience auditor with validating societal and environmental data is more recent. G4, I I: I favor the financial side, which I have better control over. I have more confidence in the data that I master. G4, I2: I have no insight on or experience in the building of these social and environmental reports. G5, I5: Not being an expert on these issues, I have only limited confidence in these data.

G2, 3: I don't think a financial auditor has the right training to analyze non-financial elements in an informed manner.

G3, 7: I ignored all the non-financial practices and the impact that it could have on company valuation. Having been trained solely in financial matters, my assessment of performance was based on the financial data alone.

G5, 9: My generation has not been made aware of or given any training on social aspects. G4, I3: I can only consider the financial, economic and legal criteria important, because I have no previous training in the analysis of environmental and social issues.

G3, 16: Professional accountants do not appear to have the training to clearly analyze companies' non-financial elements.

G5, 2: I am a specialist in financial issues but not in non-financial issues, and I think that I am currently not able to audit CSR data. My accounting skills are specific to financial audit. G2, 9: Our experience in validating CSR data is too recent for us to be considered specialists in CSR issues

G5, 2: Not being a specialist in non-financial issues, I would need the support of a sustainability expert.

G2, 9: Having no competence in social and environmental reporting, I didn't take this information into account. (...) If one of my client files had to include a significant amount of CSR information, I would call in specialists to assist me in the engagement.

G3, 7: There is a focus on financial elements considering our education. G4, I 3: Because of my education, I can only attach importance to financial, economic and legal criteria.G3, 3:The financial auditors, being censors, do not seem to me to be educated to analyze in an enlightened way the non-financial elements of the companies. G5, 6: Professional accountants are poorly educated in the analysis of non-balance sheet data and yet the value of a company depends mainly on non-transcribed values in accounting (intangible values, brands, quality of management).

G2, 3: I don't think a financial auditor has the right training to analyze non-financial elements in an informed manner.

G5, I I: Information about CSR is difficult to assess and difficult to check. The professional accountants don't have enough education to analyze these non-financial data.
Difficulties in translating the

financial accounting skims to

CSR assurance

Lack of knowledge and

education
Lack of assurance

standardization

Lack of training (experience)

Auditor's illiteracy

regarding CSR issues
Aggregated categories or attentional themes

Lack of standardization
Lack of CSR reporting

standardization
Topics on which experiment participants focused significant attention

regarding CSR issues


Table 7 (Continued). Coding data structure

Representative data (quotes)

\author{
Topics on which experiment \\ participants focused significant \\ attention
}

G3, I0: The experience auditor with validating societal and environmental data is more recent. G4, I I: I favor the financial side, which I have better control over. I have more confidence in the data that I master. G4, 12: I have no insight on or experience in the building of these social and environmental reports. G5, 15: Not being an expert on these issues, I have only limited confidence in these data.

G2, 3: I don't think a financial auditor has the right training to analyze non-financial elements in an informed manner.

G3, 7: I ignored all the non-financial practices and the impact that it could have on company valuation. Having been trained solely in financial matters, my assessment of performance was based on the financial data alone.

G5, 9: My generation has not been made aware of or given any training on social aspects. G4, I 3: I can only consider the financial, economic and legal criteria important, because I have no previous training in the analysis of environmental and social issues.

G3, 16: Professional accountants do not appear to have the training to clearly analyze companies' non-financial elements.
Aggregated categories or attentional themes
Auditor's illiteracy regarding CSR issues

CSR, corporate social responsibility.

these professionals acknowledge that they cannot transfer their experience and skills in financial auditing to the non-financial field. Not being able to carry out this type of a mission, recourse to experts in the environmental and/or social fields is suggested by professional accounting auditors. One of them confesses, "if one of my client files had to include a significant amount of CSR information, I would call in specialists to assist me in the engagement" $(G 2,9)$. Using various types of assurance providers such as environmental engineers, human resources managers, and professional accountants who make up the audit team may thus be an answer to this criticism. Finally, it seems that in addition to a lack of experience, a lack of training plays a key role in the negative professional accountants' perceptions of the effectiveness of CSRA. One of them assumes that his "generation has not been made aware or given any training on social aspects" (G5, 9). The training and experience of professional accountants make them accounting and auditing specialists, but they lack sufficient skills, knowledge, and training in the CSR field. This raises the question of the real competence of these professional accountants. The results suggest that professional accountants do not feel competent to perform CSRA due to their lack of experience and training in the field. This is likely to call into question their legitimacy to carry out these missions and to admit that other auditors with these attributes would be more competent for that purpose.

\section{Discussion and conclusion}

Our results make a theoretical contribution by offering empirical evidence contradicting the existence of a signaling effect of CSRA and suggesting, in line with legitimacy theory, that CSRA is used as a compliance exercise. However, there could be another meaning of these findings. The reasons given by professional accountants to justify their skepticism toward CSRA could serve as a strategy of justification (Taupin, 2012) for resisting changes and/or avoiding new responsibilities.

\section{CSRA:A compliance exercise}

According to signaling theory, assurance consists of producing an assurance statement that offers conclusions regarding the quality of the CSR information disclosed by firms: the major purpose is to enhance the intended users' confidence (Hodge et al., 2009). Thus, if CSRA is an effective signal, the assured CSR information should be perceived as more relevant and trustworthy than CSR information reported without assurance. Our results show the opposite. While professional accountants are themselves the providers of assurance, the participants in our experiment do not recognize benefits of CSRA with regard to an increase in the relevance of assured information and confidence in this information. The professional accountants are rather neutral regarding the relevance of CSR information, regardless of whether it is assured or not. Likewise, their level of confidence in this information does not increase when the CSRA statement is provided. In addition, professional accountants have concerns that the content of assurance statements remains too descriptive and not informative enough, contradicting the view that CSRA serves as an effective signal of the quality of information disclosed by firms.

Even if CSRA is required in France, most professional accountants have concerns regarding their own ability to correctly address the quality of CSR information and to carry out CSRA engagements. The nature of CSRA data and the lack of standardization are obstacles to the effectiveness of CSRA, and it is difficult for accountants to express a judgment on CSR 
information over which they think they have little or no control.The accountants in our study report the existence of managerial capture, making critical assessment of firms' CSR decisions and practices difficult. In addition, the accountants note the insufficiency of their own training and knowledge of CSR issues. They are financial audit specialists, and the accounting education curriculum does not provide all the skills and experiences needed to make judgments about the integrity of companies that wish to engage in CSR reporting and practice. From this point of view, our results support the argument from legitimacy theory that CSRA is useful neither for informing stakeholders nor for providing management with critical information but rather for positively influencing stakeholders' perceptions of the firm's performance.

Taken together, our results contradict the existence of a signaling effect of CSRA (e.g., Ballou et al., 20 I 8; Casey \& Grenier, 20 I 5; Kolk \& Perego, 20 I0; Simnett et al., 2009) and align with studies that criticize the practice of CSRA (Boiral, HerasSaizarbitoria, Brotherton, \& Bernard, 2019; Fonseca, 2010; Manetti \& Becatti, 2009; O'Dwyer \& Owen, 2005, 2007). They support the legitimacy perspective, whereby CSRA is used by firms as a compliance exercise. We advance the idea that firms strategically use CRSA to create the illusion of transparency by complying with French disclosure requirements.

Additionally, a minor and secondary contribution of this article is to add the idea that making CSRA mandatory, as France has done, does not enhance the effectiveness of assurance. As previously noted, the French Grenelle 2 law, by making CSRA mandatory for the largest companies, was expected to redress the weakness of CSRA (Gillet-Monjarret, 2018). However, while we might have expected that French professional accountants acknowledge the benefits and effectiveness of CSRA, our results show the opposite.

\section{Towards a strategy of justification for resisting new challenges in CSRA}

With the adoption of the Grenelle 2 law, France ushered in a new market for CSRA in which all accounting firms of any type and size are recognized as competent to carry out CSR assurance engagement. Paradoxically, this results in a dichotomy in the assurance field between Big 4 firms, which have a competitive advantage, and non-Big 4 firms, which lack time and resources to invest in CSRA. Indeed, as noted by Larrinaga et al. (20 | 8), Big 4 firms have a quasi-monopoly on performing CSRA. They are recognized as having the greatest legitimacy to carry out this mission (Canning, O'Dwyer, \& Georgakopoulos, $2019)$. Furthermore, as the implementation of CSRA requires a variety of skills that require joint work by accounting professionals, specialized engineers, and various environmental experts, large firms have extensive experience in cooperating with other experts and are used to calling in the technical expertise that they may lack (Beets \& Souther, 1999; Lightbody, 2000). They also have the capacity to create economies of scale and invest in training and/or new technologies. The emergence of the new CSRA market is driving Big 4 companies to make substantial investments in training so that their members can provide more accurate assurance statements (Hodge et al., 2009; Martinez-Ferrero \& Garcia-Sanchez, 2016). In contrast, non-Big 4 firms seem unable to carry out this type of mission due to a lack of time and resources to invest in CSRA.

Facing this situation, a struggle could be taking place between accounting firms, with some of them (non-Big 4) seeking to resist change and maintain the status quo and others (Big 4) opposing that aim. As noted by Taupin (2012), in the event of change in an institutional field, tensions emerge with the presence of different logics that may compete with each other. Based on this idea, we can assume that some professional accountants pursue a strategy of justification for resisting the changes imposed by the implementation of mandatory CSRA and/or for avoiding new responsibilities. Among the reasons given to justify their skepticism toward CSRA, participants in the experiment mentioned their own CSR 'illiteracy' and the lack of coherent standards. However, these arguments are all the more surprising because $(I)$ in French law, all professional accountants, not only accountants from Big 4 firms, are recognized as competent to carry out CSR assurance engagements; and (2) the CNCC has promulgated a professional practice standard for CSRA. In addition, we note that experiment participants also mentioned their high level of specialization in finance. Taken together, these findings suggest that some professional accountants may refuse to deal with the new challenges of CSRA and seek to maintain the status quo by reinforcing their own legitimacy in the financial audit field. For this purpose, they could use both their lack of knowledge and experience of CSR issues (in other words, their CSR 'illiteracy') and the lack of standardization as a strategy of justification (Taupin, 2012).

Note that this interpretation of the findings is consistent with the characteristics of the professional accountants participating in our experiment. First, they have an average of 19.81 years of experience, and auditors with more experience are likely to have a more negative view of the important change made regarding CSRA in the audit profession. Second, even if the affiliation of participants with Big 4 and non-Big 4 firms has not been identified, we can assume that most accountants participating in our experiment work in non-Big 4 firms because of the French audit market structure composed of many small audit firms.

\section{Limitations and avenues for future research}

This study presents some limitations, and the generalizability of our results cannot be guaranteed for at least two main reasons. First, our experimental questionnaire study is based on a 
specific setting with a lower complexity than that of a real-life setting. For example, the set of documents used contained a limited volume of information. In real life, potential users have various information sources available to make their judgments of firms' performance. Second, as our study concerns the French regulatory setting, the results are primarily valid in this specific context. Apart from France, there are two other European countries (Italy and Spain) where having CSRA carried out by an independent third party has recently become mandatory. Furthermore, a comparative study on the effectiveness of CSRA could be conducted by considering two different settings, one in which CSRA is mandatory and another in which it is voluntary. More specifically, Pennings (2017) noted the need for future research to assess the consequences of mandatory CSR assurance. Finally, as professional accountants do not consider themselves sufficiently competent and trained to carry out CSRA, it would also be interesting to deepen our understanding of their perceptions by using a purely qualitative study in line with the work of Boiral, Heras-Saizarbitoria, Brotherton, \& Bernard (2019). Future research could be based on semistructured interviews to identify the accountants' current willingness and their requirements to provide mandatory CSRA.

\section{Acknowledgments}

The authors gratefully acknowledge the comments of the co-editor Thomas Roulet and the anonymous reviewers. They are grateful to the French National Institute of Auditors (Compagnie Nationale des Commissaires aux Comptes) for granting them access to its directory of members.

\section{References}

Ball, A., Owen, D. L. \& Gray, R. (2000). External transparency or internal capture? The role of third-party statements in adding value to corporate environmental reports. Business Strategy and the Environment, 9( I), I-23. doi: I0. I 002/(SICl) I099-0836(20000 I/02)9: | 3.0.CO;2-H

Ballou, B., Chen, P. C., Grenier, J. H. \& Heitger, D. L. (20 I 8). Corporate social responsibility assurance and reporting quality: Evidence from restatements. Journal of Accounting and Public Policy, 37(2), 167-188. doi: I0. 10 | 6/j.jaccpubpol.20 | 8.02.00 |

Beets, S. D. \& Souther, C. C. (1999). Corporate environmental reports:The need for standards and an environmental assurance service. Accounting Horizons, 13(2), 129-145. doi: I0.2308/acch. 1999.13.2. 129

Boiral, O., Heras-Saizarbitoria, I. \& Brotherton, M. C. (2019). Assessing and improving the quality of sustainability reports: The auditors' perspective. Journal of Business Ethics, 155(3), 703-721. doi: 10.1007/ sl055|-017-35।6-4

Boiral, O., Heras-Saizarbitoria, I., Brotherton, M. C. \& Bernard, J. (2019). Ethical issues in the assurance of sustainability reports: Perspectives from assurance providers. Journal of Business Ethics, I 59(4), I | | |- | | 25. doi: | 0.1007/s | 055 |-0 | 8-3840-3

Braam, G. \& Peeters, R. (20|8). Corporate sustainability performance and assurance on sustainability reports: Diffusion of accounting practices in the realm of sustainable development. Corporate Social Responsibility and Environmental Management, 25, 164-181. doi: 10.1002/csr. 1447

Briem, C. R. \&Wald, A. (20 I8). Implementing third-party assurance in integrated reporting: Companies' motivation and auditors' role. Accounting, Auditing and Accountability Journal, 3/(5), |46|-|485. doi: I0.| I08/ AAAJ-03-2016-2447

Brown-Liburd, H. \& Zamora, V. L. (20I5). The role of corporate social responsibility (CSR) assurance in investors' judgments when managerial pay is explicitly tied to CSR performance. Auditing: A Journal of Practice and Theory, 34(I), 75-96. doi: 10.2308/ajpt-508I3

Canning, M., O'Dwyer, B. \& Georgakopoulos, G. (2019). Processes of auditability in sustainability assurance: The case of materiality construction. Accounting and Business Research, 49(I), I-27. doi: 10.1080/000 I 4788.20I8.1442208

Carey, P., Simnett, R. \& Tanewski, G. (2000). Voluntary demand for internal and external auditing by family businesses. Auditing: A Journal of Practice and Theory, 19, 37-5 I. doi: 10.2308/AUD.2000.19.S-1.37

Casey, R. J. \& Grenier, J. H. (20।5). Understanding and contributing to the enigma of corporate social responsibility (CSR) assurance in the United States. Auditing: A Journal of Practice and Theory, 34(I), 97-130. doi: 10.2308/ajpt-50736

Cheng, M. M., Green, W. J. \& Chi Wa Ko, J. (2015). The impact of strategic relevance and assurance of sustainability indicators on investors' decisions. Auditing: A Journal of Practice and Theory, 34(1), |31-162. doi: 10.2308/ajpt-50738

Chiang, C. (2006). Auditors' perceptions of environmental issues and its implication for the consideration of environmental matters. New Zealand Journal of Applied Business, 5(2), 17-24.

Chiang, C. \& Northcott, D. (20I2). Financial auditors and environmental matters: Drivers of change to current audit practices. Journal of Accounting \& Organizational Change, 8(3), 340-363. doi: | 0.1 | 08/|83259||2| |258335

Cho, C. H., Laine, M., Roberts, R. W. \& Rodrigue, M. (20।5). Organized hypocrisy, organizational façades, and sustainability reporting. Accounting, Organizations and Society, 40, 78-94. doi: I0.1016/j.aos.20I4. I2.003

Cho, C. H., Michelon, G. \& Patten, D. M. (20I4). CSR report assurance in the USA: An empirical investigation of the determinants and effects. Sustainability Accounting, Management and Policy Journal, 5(2), | 30-| 48. doi: I0.I I08/SAMPJ-0 I-20|4-0003

Cho, C. H. \& Patten, D. M. (2007). The role of environmental disclosures as tools of legitimacy: A research note. Accounting, Organizations and Society, 32(7-8), 639-647. doi: I0. 10 I 6/j.aos.2006.09.009

Cisneros, L. \& Deschamps, B. (20 I5). The role of advisors and the sequence of their actions in sibling team succession. M@n@gement, 18(4), 282-308. doi: | 0.39 | 7/mana. 184.0282

Clarkson, M. B. E. (1995). A stakeholder framework for analyzing and evaluating corporate social performance. Academy of Management Review, 20( I), 92-I I7. doi: I0.5465/amr.1995.9503271994

Clarkson, P., Li, Y., Richardson, G. \& Tsang, A. (2019). Causes and consequences of voluntary assurance of CSR reports: International evidence involving Dow Jones Sustainability Index Inclusion and Firm Valuation. Accounting, Auditing \& Accountability Journal, 32(8), 245I-2474. doi: 10.1 I08/AAAJ-03-2018-3424

Cohen, J. R. \& Simnett, R. (20I5). CSR and assurance services: A research agenda. Auditing: A Journal of Practice and Theory, 34(I), 59-74. doi: 10.2308/ajpt-50876

Corbin, J. \& Strauss, A. (2008). Basics of qualitative research: Techniques and procedures for developing grounded theory. Sage.

Dixon, R., Mousa, G. \& Woodhead, A. (2004). The necessary characteristics of environmental auditors: A review of contribution of the financial 
auditing profession. Accounting Forum, 28, 119-138. doi: 10.1016/j. accfor.2004.01.001

Edmondson, A. C. \& McManus, S. E. (2007). Methodological fit in management field research. Academy of Management Review, 32(4), I I 55- 1 I 79. doi: |0.2307/20|5936 |

Epstein, M. \& Geiger, M. (1994). Investor views of audit assurance: Evidence of the expectation gap. Journal of Accountancy, 177(1), 60-66. doi: I $0.1108 / 02686909810208038$

Farooq, M. \& De Villiers, C. (2019). Sustainability assurance: Who are the assurance providers and what do they do?: Reporting, taxation, ethics and governance. In S. Ardvisson (Ed.), Challenges in managing sustainable business (pp. 137-154). Palgrave MacMillan.

Fernandez-Feijoo, B., Romero, S. \& Ruiz, S. (2012). Measuring quality of sustainability reports and assurance statements: Characteristics of the high-quality reporting companies. International Journal Society Systems Science, 4(I), 5-27. doi: I0.1504/IJSSS.20 I 2.04537|

Fonseca, A. (2010). How credible are mining corporations' sustainability reports? A critical analysis of external assurance under the requirements of the international council on mining and metals. Corporate Social Responsibility and Environmental Management, 17(6), 355-370. doi: 10.1002/csr.230

Gay, G., Schelluch, P. \& Baines, A. (1998). Perceptions of messages conveyed by review and audit reports. Accounting, Auditing \& Accountability Journal, II (4), 472-494. doi: | 0. I |08/095 | 35798 I 023 | 493

Gillet-Monjarret, C. (20 | 8). Assurance reports included in the CSR reports of French firms: A longitudinal study. Sustainability Accounting, Management and Policy Journal, 9(5), 570-594. doi: 10.1108/ SAMPJ-09-2017-0098

Gioia, D. A., Corle, K. G. \& Hamilton, A. L. (20।2). Seeking qualitative rigor in inductive research notes on the Gioia methodology. Organizational Research Methods, I 6( I), I5-31. do: I 0. I I77// 094428 I I2452 I5 I

Global Reporting Initiative (GRI). (20I3). Reporting principles and standard disclosures, versions. Retrieved from www.globalreporting.org/guidelines

Goicoechea, E., Gomez-Bezares, F. \& Ugarte, J.V. (20 I 9). Integrated reporting assurance: Perceptions of auditors and users in Spain. Sustainability, I | (3), 7| 3. doi: I0.3390/sul I0307|3

Green, W. \& Li, Q. (20I2). Evidence of an expectation gap for greenhouse gas emissions assurance. Accounting, Auditing \& Accountability Journal, 25( I), | 46-173. doi: I0.1 108/095 | 357| 21 | | 191789

Gürtürk, A. \& Hahn, R. (2016). An empirical assessment of assurance statements in sustainability reports: Smoke screens or enlightening information? Journal of Cleaner Production, 136(Part A), 30-41. doi: 10.1016/j. jclepro.2015.09.089

Habek, P. \& Wolniak, R. (2015). Assessing the quality of corporate social responsibility reports: The case of reporting practices in selected European Union member states. Quality and Quantity, 50(I), 399-420. doi: | 0. I007/s | | |35-0 |4-0 I55-z

Hassan, A., Elamer, A., Sobhan, N. \& Fletcher, M. (2019).Voluntary assurance of sustainability reporting: Evidence from an emerging economy. Accounting Research Journal, 33(2), 39I-4I0. doi: I0.1 I08/ARJ-I02018-0169

Hodge, K., Subramaniam, N. \& Stewart, J. (2009). Assurance of sustainability reports: Impact on report users' confidence and perceptions of information credibility. Australian Accounting Review, 19(3), 178-194. doi: | 0.1 | | | /j. | 835-2561.2009.00056.x

Huggins, A., Green, W. J. \& Simnett, R. (20I I). The competitive market for assurance engagements on greenhouse gas statements: Is there a role for assurers from the accounting perspective? Current Issues in Auditing, 5(2), A I-A I2. doi: I0.2308/ciia-50083
Hummel, K., Schlick, C. \& Fifka, M. (2019). The role of sustainability performance and accounting assurors in sustainability assurance engagements. Journal of Business Ethics, 154(3), 733-754. doi: | 0.1007/s | 055 |-016-34 | 0-5

Humphrey, C., Moizer, P. \& Turley, S. (1993). The audit expectation gap in Britain: An empirical investigation. Accounting and Business Research, 23, 395-4 | I. doi: | 0. I080/000 | 4788. 1993.9729907

International Auditing and Assurance Standards Board. (20 I I). ISAE3000 (Revised). Assurance engagements other than audits or reviews of historical financial information.

International Auditing and Assurance Standards Board- IAASB. (201 I, April). ISAE3000 (Revised). Assurance engagements other than audits or reviews of historical financial information. Retrieved from: https://www.ifac. org/system/files/publications/exposure-drafts/IAASB_ISAE_ 3000_ED.pdf

ISAE 3000. (2013). Assurance engagements other than audits or reviews of historical financial information. International Standard on Assurance Engagements.

Islam, M. \& Dellaportas, S. (20II). Perceptions of corporate social and environmental accounting and reporting practices from accountants in Bangladesh. Social Responsibility Journal, 7(4), 649-664. doi: |0.1108/1747|1111111175191

Janggu, T., Darusi, F., Sawani,Y. \& Zain, M. (2013). Assurance of CSR and sustainability reports: Empirical evidence from an emerging economy. Journal of Energy Technologies and Policy, 3(I I), 390-396. ISSN 2224-3232.

Kolk, A. \& Perego, P. (20I0). Determinants of adoption of sustainability assurance statements: An international investigation. Business Strategy and the Environment, 19(3), 182-198. doi: 10.1002/bse.643

KPMG (2015). Currents of changes. The KPMG survey of Corporate Responsibility Reporting. Retrieved from https://assets.kpmg/content/ dam/kpmg/pdf/20 I 6/02/kpmg-international-survey-of-corporate-responsibility-reporting-20I5.pdf

KPMG (2017). The KPMG survey of corporate responsibility reporting 2017. Retrieved from https://assets.kpmg/content/dam/kpmg/xx/pdf/2017/ I0/kpmg-survey-of-corporate-responsibility-reporting-20 17.pdf

Larrinaga, C., Rossi, A., Luque-Vilchez, M. \& Núñez-Nickel, M. (20l8). Institutionalization of the contents of sustainability assurance services: A comparison between Italy and United States. Journal of Business Ethics, I 63(I), 67-83. doi: 10.1007/s I055 I-0 I 8-40 I4-z

Laszczuk, A. \& Mayer, J. C. (2020). Unpacking business model innovation through an attention-based view. M@n@gement, 23(I), 38-60. doi: 10.37725/mgmt.v23.4426

Le Breton, M. \& Aggeri, F. (20 I 8). Counting before acting? The performativity of carbon accounting called into question - Calculation acts and dispositifs in a big French construction company. M@n@gement, 2 I (2), 834-857. doi: I0.39|7/mana.212.0834

Lightbody, M. (2000). Environmental auditing: The audit theory gap. Accounting Forum 24, 2, I 5 I-169. doi: I 0. I I | | | | 467-6303.00033

Lock, I. \& Seele, P. (20 I7). Measuring credibility perceptions in CSR communication: A scale development to test readers' perceived credibility of CSR reports. Management Communication Quarterly, 31 (4), 584-613. doi: 10.1 177/0893318917707592

Manetti, G. \& Becatti, L. (2009). Assurance services for sustainability reports: Standards and empirical evidence. Journal of Business Ethics, 87, 289-298. doi: | 0. I007/s I055 I-008-9809-x

Martinez-Ferrero, J. \& Garcia-Sanchez, I. M. (20।6). The level of sustainability assurance:The effects of brand reputation and industry specialization of assurance providers. Journal of Business Ethics, 150(4), 97I-990. doi: | 0.1007/s| 055 I-016-3159-x 
McEnroe, J. E. \& Martens, S. C. (200I). Auditor's and investors' perception of the "expectation gap." Accounting Horizons, 15(4), 345-358. doi: 10.2308/acch.200।.15.4.345

Michelon, G., Pilonato, S. \& Ricceri, F. (2015). CSR reporting practices and the quality of disclosure: An empirical analysis. Critical Perspectives on Accounting, 33, 59-78, doi: 10.1016/j.cpa.2014.10.003

Miles, M. B. \& Huberman, A. M. (1994). Qualitative data analysis: An expanded sourcebook (2nd ed.). Sage.

Monroe, G. S. \& Woodliff, D. R. (1993). The effect of education on the audit expectation gap. Accounting and Finance, 33(1), 6I-78. doi: 10.1 | | | /j. I 467-629X.1993.tb00195.x

O'Dwyer, B. (2003). Conceptions or corporate social responsibility: The nature of managerial capture. Accounting, Auditing and Accountability Journal, I 6(4), 523-557. doi: I0.I I08/095 I35703 I0492290

O'Dwyer, B. (201 I). The case of sustainability assurance: Constructing a new assurance service. Contemporary Accounting Research, 28(4), |230-1266. doi: 10.1 | | |/j. 191 |-3846.201 1.01 |08.x

O'Dwyer, B. \& Owen, D.L. (2005). Assurance statement practice in environmental, social and sustainability reporting: A critical evaluation. The British Accounting Review, 37(2), 205-229. doi: I0. I 0 I6/j.bar.2005.0 I.005

O'Dwyer, B. \& Owen, D. L. (2007). Seeking stakeholder centric assurance: An examination of recent sustainability assurance practice. Journal of Corporate Citizenship, 25, 77-94. doi: 10.9774/GLEAF.4700.2007. sp.00009

Owen, D. L., Swift, T. A., Humphrey, C. \& Bowerman, M. (2000). The new social audits: Accountability, managerial capture or the agenda of social champions? The European Accounting Review, 9(1), 8I-98. doi: 10.1080/096381800407950

Pennings, F. (2017). Assurance of corporate social responsibility (CSR) reports and capital market benefits in a European setting. Radboud University.

Perego, P. \& Kolk, A. (20I2). Multinationals' accountability on sustainability: The evolution of third-party assurance of sustainability reports. Journal of Business Ethics, I I0(2), 173-190. doi: 10.1007/s I055 I-012-1420-5

Pflugrath, G., Roebuck, P. J. \& Simnett, R. (20I I). Impact of assurance and assurer's professional affiliation on financial analysts? Assessment of credibility of corporate social responsibility information. Auditing: A Journal of Practice and Theory, 30(3), 239-254. doi: 10.2308/ajpt- 10047

Power, M. (199|). Auditing and environmental expertise: Between protest and professionalisation. Accounting, Auditing \& Accountability Journal, 4(3). doi: |0.1 |08/095 |3579| |0|4|75 |
Power, M. K. ( $199 \mid$ ). Educating accountants:Towards a critical ethnography. Accounting, Organizations and Society, 16(4), 333-353. doi: 10.1016/ 036I-3682(91)90026-B

Power, M. K. (1997). Expertise and the construction of relevance: Accountants and environmental audit. Accounting, Organizations and Society, 22(2), 123-146. doi: 10.1016/S0361-3682(96)00037-2

Roebuck, P., Simnett, R. \& Ho, H. L. (2000). Understanding assurance services reports: A user perspective. Accounting \& Finance, 40(3), 21 I-232. doi: |0. I | | |/ |467-629X.00045

Romero, S., Fernandez-Feijoo, B. \& Ruiz, S. (2014). Perceptions of quality of assurance statements for sustainability reports. Social Responsibility Journal, 10(3), 480-499. doi: 10.1 I08/SRJ-10-2012-0130

Simnett R., Vanstraelen, A. \& Fong Chua, W. (2009). Assurance on sustainability reports: An international comparison. The Accounting Review, 84(3), 937-967. doi: 10.2308/accr.2009.84.3.937

Smith, J., Haniffa, R. \& Fairbrass, J. (20I I). A conceptual framework for investigating "capture" in corporate sustainability reporting assurance. Journal of Business Ethics, 99(3), 425-439. doi: 10.1007/s1055I$010-066 \mid-4$

Taupin, B. (2012). The more things change... institutional maintenance as justification work in the credit rating industry. M@n@gement, 15(5), 529-562. doi: 10.3917/mana. 155.0529

Touboul, S.\& Kozan,A. (2020). “You cannot hide Forever Luke”: Understanding the strategic use of sustainability disclosure in the short and long term. M@n@gement, 23( I), 19-37. doi: 10.37725/mgmt.v23.4427

Williams, J. \& Elson, R. J. (2010). The challenges and opportunities of incorporating accounting ethics into the accounting curriculum. Journal of Legal, Ethical \& Regulatory Issues, 13(1), |05-1 I5.

Wong, R. \& Millington, A. (20|4). Corporate social disclosures: A user perspective on assurance. Accounting, Auditing \& Accountability Journal, 27(5), 863-887. doi: 10.1 I08/AAAJ-06-2013-1389

Zhou, S., Simnett, R. \& Green,W. (20 I 6). Assuring a new market:The interplay between country-level and company-level factors on the demand for Greenhouse Gas (GHG) information assurance and the choice of assurance provider. Auditing: A Journal of Practice and Theory, 35(3), |4|-|68. doi: 10.2308/ajpt-5 | 4 |4

Zorio, A., Garcia-Benau, M. A. \& Sierra, L. (20/3). Sustainability development and the quality of assurance reports empirical evidence. Business Strategy and the Environment, 22(7), 484-500. doi: 10.1002/ bse. 1764 